\title{
The Role of Tungsten Oxide in the Enhancement of Carbon Monoxide Tolerance of Platinum-Based Hydrogen Oxidation Catalysis
}

\author{
Douglas W. G. Stewart ${ }^{1,2}$, Keith Scott ${ }^{2}$, Andrew J. Wain ${ }^{3}$, Timothy E. Rosser ${ }^{3}$, \\ Edward Brightman ${ }^{1,4}$, Donald Macphee ${ }^{1,5}$, Mohamed Mamlouk ${ }^{2}$.
}

${ }^{1}$ Enocell Ltd., BioCity Scotland, Motherwell, ML1 5UH.

${ }^{2}$ Chemical Engineering, Newcastle University, Newcastle upon Tyne, NE1 7RU.

${ }^{3}$ National Physical Laboratory, Hampton Rd, Teddington, TW11 0LW.

${ }^{4}$ Department of Chemical and Process Engineering, University of Strathclyde, Glasgow, G1 1XJ.

${ }^{5}$ Department of Chemistry, University of Aberdeen, AB24 3UE.

E-mail: d.stewart2@ncl.ac.uk

\begin{abstract}
Significant reductions in total cost of ownership can be realised by engineering PEM fuel cells to run on low-purity hydrogen. One of the main drawbacks of low-purity hydrogen fuels is the carbon monoxide fraction, which poisons platinum electrocatalysts and reduces the power output below useful levels. Platinum-tungsten oxide catalyst systems have previously shown high levels of CO tolerance in both ex situ and in situ investigations. In this work we explore the mechanism of enhanced tolerance using in situ electrochemical attenuated total reflection infrared (ATR-IR) and Raman spectroscopic methods, and investigate, using a mixture of $\mathrm{Pt} / \mathrm{C}$ and $\mathrm{WO}_{3}$ powders, the role of the $\mathrm{W}^{\mathrm{V}} / \mathrm{W}^{\mathrm{VI}}$ redox couple in the oxidation of adsorbed $\mathrm{CO}$.
\end{abstract}

Keywords: fuel cell, hydrogen, ATR-IR, carbon monoxide oxidation, tungsten trioxide, platinum. 


\section{Introduction}

Government-backed adoption of hydrogen technology in countries such as China ${ }^{1}$ indicates that widespread uptake of fuel cell technology could be realised in the near future. The challenges now faced by the fuel cell community are to reduce costs and ensure the long-term sustainability of the technology.

Given that the cost of platinum dominates the overall cost of typical Polymer Electrolyte Membrane Fuel Cell (PEMFC) stack production (estimated at $\sim 49 \%$ at 500,000 units/year) ${ }^{2}$, it is widely accepted that reduction or elimination of platinum-group metals (PGMs) is the most direct method of significantly reducing the cost of hardware, and significant progress has been made in this arena, as demonstrated by Ballard's recent addition of a PGM-free catalyst to their fuel cell portfolio ${ }^{3}$. Capital expenditure is, however, only one part of the lifetime cost of fuel cells, and to bring fuel cell technology to the masses we must also consider operational expenditure: the cost of fuel. Despite improvements to electrolyser technology, hydrogen production from water currently comprises less than $10 \%$ of global production ${ }^{4}$, with the vast majority being sourced from fossil fuels via steam reformation. A fuel cell running on hydrogen derived from the latter represents a useful stop-gap measure while electrolyser capacity is increased, or may become a more sustainable solution in the context of carbon capture, utilisation and storage, and there is potential to drastically reduce the cost of hydrogen for fuel cell applications if this impure reformate can be used with minimal processing.

Typical hydrogen from methanol or methane reformation contains $\sim 2 \%$ carbon monoxide ${ }^{5}$, which is far too high for even the most tolerant low-temperature PEM catalysts at present. Further processing can reduce the content below $2 \mathrm{ppm}^{6}$, increasing the cost of fuel; based on supplier websites ${ }^{7}$, utilisation of hydrogen at $99.99 \%$ purity rather than at $99.999 \%$ (ISO 14687 specification for PEM applications) indicates a cost saving of $>70 \%$.

Carbon monoxide presents a problem in PEM fuel cells due to the large overpotentials required to oxidise the molecule to $\mathrm{CO}_{2}{ }^{6}$. $\mathrm{CO}$ bonds strongly to the Pt surface ${ }^{6}$, inhibiting surface site availability for hydrogen oxidation; the potential of the anode must increase to remove $\mathrm{CO}$ via oxidation (equation 1), causing the cell voltage to drop significantly. The formation of hydroxide groups on the surface of $\mathrm{Pt}$ (equation 2) is the limiting step in oxidation of $\mathrm{CO}$ and is the reason for the large overpotential requirement.

$$
\begin{gathered}
\mathrm{Pt}-\mathrm{CO}_{\mathrm{ads}}+\mathrm{Pt}-\mathrm{OH}_{\mathrm{ads}} \rightarrow \mathrm{CO}_{2}+\mathrm{H}^{+}+\mathrm{e}^{-} \\
\mathrm{Pt}+\mathrm{H}_{2} \mathrm{O} \rightarrow \mathrm{Pt}-\mathrm{OH}_{\mathrm{ads}}+\mathrm{H}^{+}+\mathrm{e}^{-} \quad \text { (2) } E>0.6 V_{R H E}
\end{gathered}
$$

The current state-of-the-art catalyst to mitigate this poisoning effect is a platinum-ruthenium alloy. PtRu/C catalysts alleviate the CO poisoning problem via two mechanisms: (i) depletion of the Pt 5d orbital occupancy resulting in decreased saturation coverage $(\theta<0.6)$ and increased $\mathrm{CO}$ surface mobility ${ }^{7}$ (referred to as the "electronic mechanism"), and (ii) the formation of - $\mathrm{OH}$ groups on $\mathrm{Ru}$ at lower potentials than occurs on pure $\mathrm{Pt}$ $\left(E \sim 0.4 \mathrm{~V}_{\mathrm{RHE}}\right)$, known as the "bifunctional mechanism" ${ }^{8,9}$. The maximum $\mathrm{CO}$ tolerance of PtRu/C catalysts is ultimately limited by the potential of $-\mathrm{OH}_{\text {ads }}$ formation; while some studies have claimed this can begin as low as $0.25 \mathrm{~V}_{\mathrm{RHE}}{ }^{10}$, most agree that bulk Ru-OH formation takes place at $E>0.4 \mathrm{~V}_{\mathrm{RHE}}{ }^{11-13}$. While this is an improvement on pure $\mathrm{Pt}$, this potential is still relatively high when considering the optimal operating potentials of PEMFC anodes $\left(E<0.2 \mathrm{~V}_{\mathrm{RHE}}\right)$. As an alternative, $\mathrm{Pt} \mid \mathrm{WO}_{3}$ systems may have the potential to provide superior behaviour, having been shown in the literature to facilitate the oxidation of $\mathrm{CO}$ at potentials as low as $0.1 \mathrm{~V}_{\mathrm{RHE}}{ }^{14}$.

$\mathrm{WO}_{3}$ is well-established in enhancing the tolerance of $\mathrm{Pt}$ and PtRu catalysts to $\mathrm{CO}{ }^{15-17}$, and has demonstrated the ability to facilitate the oxidation of $\mathrm{CO}$ on $\mathrm{Pt}$ at potentials well below that of $\mathrm{Ru}^{14,18-21}$. If that ability can be fully exploited, $\mathrm{Pt} \mid \mathrm{WO}_{3}$ electrodes could present an alternative to $\mathrm{PtRu}$, and perhaps more importantly, could open up the possibility of utilising fuels with high levels of carbon monoxide.

The mechanism of the $\mathrm{CO}$ tolerance of $\mathrm{Pt} \mid \mathrm{WO}_{3}$ composites is thought to be a predominantly bifunctional one ${ }^{19,20}$; proximal W-OH groups react with Pt- $\mathrm{CO}_{\text {ads }}$ to produce $\mathrm{CO}_{2}$ at potentials not limited by the formation of $\mathrm{Pt}-\mathrm{OH}$ species. A previous study of a $\mathrm{Pt} \mid \mathrm{WO}_{3}$ catalyst concluded that the role of $\mathrm{WO}_{3}$ is to provide oxygencontaining species at low electrode potentials ${ }^{14}$. They postulated that these $\mathrm{W}-\mathrm{OH}$ species are the product of tungsten bronze $\left(\mathrm{H}_{\mathrm{x}} \mathrm{WO}_{3}\right)$ formation at low electrode potentials $\left(\sim 0.2 \mathrm{~V}_{\mathrm{RHE}}\right)$. X-ray photoelectron spectroscopy (XPS) showed a lowering in the binding energy (B.E.) of $\mathrm{Pt}_{4 \mathrm{f}}$ electrons, suggesting a strong-metal-supportinteraction (SMSI), however the change in $\mathrm{Pt}_{4 \mathrm{f}}$ electron B.E. indicated an increase in electron density, opposite to the effect of PtRu alloying, and therefore not contributing to enhanced $\mathrm{CO}$ tolerance. Based on the work of Igarashi et al. ${ }^{7}$ they suggest that the negative shift in $\mathrm{Pt}_{4 \mathrm{f}}$ electron B.E. results in a stronger Pt-CO bond and consequently 
higher surface $\mathrm{CO}$ coverage and decreased $\mathrm{CO}$ mobility; properties that would be expected to have a negative impact on $\mathrm{CO}$ tolerance of a Pt-based catalyst.

$\mathrm{WO}_{3}$-supported Pt catalysts suffer from the low conductivity of the metal oxide substrate, and as such have low electrochemical surface areas (ECSAs) in comparison to $\mathrm{Pt} / \mathrm{C}{ }^{20}$. If a bifunctional mechanism is at work, a chemical bond between the components may not be necessary for an enhancement in $\mathrm{CO}$ tolerance. A mixture of $\mathrm{Pt} / \mathrm{C}$ and $\mathrm{WO}_{3}$ powders, if $\mathrm{WO}_{3}$ is in excess and the co-catalysts adequately mixed, could provide a high level of $\mathrm{CO}$ tolerance while maintaining high electrical conductivity and not hampering performance, as well as offering important advantages in preparation simplicity and scalability.

In this work we explore the viability of a physical mixture system ( $\mathrm{Pt} / \mathrm{C}$ mixed with $\mathrm{WO}_{3}$ powder) as a $\mathrm{CO}$ tolerant low-temperature PEM hydrogen oxidation catalyst and look to further clarify the mechanism of CO tolerance enhancement in $\mathrm{Pt} \mid \mathrm{WO}_{3}$ systems. Due to the multiple components in the system, which are dynamic with respect to the potential applied, and the possibility of at least two established CO tolerance mechanisms to distinguish, we supplement electrochemical techniques with two complementary in situ spectroscopic techniques. We investigate the role of $\mathrm{W}^{\mathrm{V}} / \mathrm{W}^{\mathrm{VI}}$ in the accepted bifunctional mechanism via in situ Raman spectroscopy and use in situ attenuated total reflection infrared (ATR-IR) spectroscopy to monitor the effect of $\mathrm{WO}_{3}$ addition on both $\mathrm{CO}$ coverage and binding modes to $\mathrm{Pt}$ as a function of potential, with the aim of elucidating any electronic effects imparted by $\mathrm{WO}_{3}$ on the Pt surface.

\section{Experimental}

\subsection{Catalyst Synthesis and Ink Preparation}

Tungsten trioxide was synthesised via reaction of the appropriate weight of sodium paratungstate (Sigma Aldrich 510114-100G) with nitric acid (Sigma Aldrich 438073) in deionised water. The hydrated product was extracted and washed via vacuum filtration and calcined in air at $550{ }^{\circ} \mathrm{C}$ for 4 hours, then milled to give the final product.

Electrochemical evaluation of the catalysts was undertaken via thin-film electrode measurements. The preparation of these thin film electrodes was achieved via a drop-casting method whereby an aliquot of waterbased catalyst ink ( $0.8 \mathrm{mg} / \mathrm{mL} 46.1$ w.t. $\%$ Pt/C, $4.0 \mu \mathrm{L} / \mathrm{mL}$ Nafion D2020, $\left.1.48 \mathrm{mg} / \mathrm{mL} \mathrm{WO}_{3}\right)$ was applied to a glassy carbon electrode and allowed to dry under ambient conditions while rotating at $700 \mathrm{rpm}$. A commercial $\mathrm{Pt} / \mathrm{C}$ catalyst (Tanaka TEC10E50E) was employed as the control sample (hereafter referred to as "Pt/C") and this was mixed with the as-synthesised $\mathrm{WO}_{3}$ powder to produce the physical mixture catalyst sample (hereafter referred to as "Pt/C/ $/ \mathrm{WO}_{3}$ ").

Inks for ATR-IR and Raman spectroelectrochemistry contained the catalysts in the same ratios; however, the technique required more dilute ink recipes, as follows; Ink 1 (control): $0.19 \mathrm{mg} / \mathrm{mL} 46.1 \%$ wt. Pt/C; $1 \mu \mathrm{L} / \mathrm{mL}$ $20 \%$ wt. Nafion. Ink 2: $0.19 \mathrm{mg} / \mathrm{mL} 46.1 \%$ wt. Pt $/ \mathrm{C} ; 1 \mu \mathrm{L} / \mathrm{mL} 20 \%$ wt. Nafion; $0.36 \mathrm{mg} / \mathrm{mL} \mathrm{WO}_{3}$.

\subsection{Structural Analysis}

\subsubsection{Electron Microscopy}

Transmission electron microscopy (TEM) images were captured using a Hitachi HT7800 transmission electron microscope using an Emsis Xarosa camera with radius software. Samples were suspended in ethanol and drop-cast onto a copper grid and dried under an IR lamp.

Scanning electron microscopy (SEM) images were captured using a Carl Zeiss GeminiSEM 300 - high resolution Field Emission Scanning Electron Microscope (FESEM) fitted with SE (secondary electron) and BSE (backscattered electron) detectors. Catalyst samples were drop-cast on adhesive carbon stubs using the electrode catalyst inks given in section 2.1.

\subsubsection{XRD}

Powder X-ray diffraction (XRD) patterns were recorded on a PANalytical X'Pert Pro X-ray diffractometer (45 $\mathrm{kV}, 40 \mathrm{~mA}$ ) using $\mathrm{Cu} \mathrm{K} \alpha$ radiation. 


\subsubsection{XPS}

XPS was performed on a Thermo Fisher Scientific NEXSA spectrometer using a microfocused monochromatic Al X-ray source $(72 \mathrm{~W})$ over an area of approximately $100 \mu \mathrm{m}^{2}$. Data were recorded at pass energies of $150 \mathrm{eV}$ for survey scans and $40 \mathrm{eV}$ for high resolution scans with $1 \mathrm{eV}$ and $0.1 \mathrm{eV}$ step sizes, respectively. Charge neutralization of the sample was achieved using a combination of both $\mathrm{Ar}^{+}$ions and low energy electrons. The XPS data was analysed using CasaXPS v2.3.19 software using sensitivity factors supplied by the manufacturer with all binding energies referenced to the C (1s) peak at $284.5 \mathrm{eV}$.

\subsection{Electrochemistry}

Electrochemical experiments were conducted in $0.1 \mathrm{M} \mathrm{H}_{2} \mathrm{SO}_{4}$ electrolyte using a Pt foil counter electrode, reversible hydrogen (RHE) reference electrode, and a rotating disk electrode (RDE) working electrode, under rotation where specified. Electrodes were initially conditioned via 20 cyclic voltammograms (CVs, $100 \mathrm{mV} / \mathrm{s})$, followed by 3 slower CVs $(10 \mathrm{mV} / \mathrm{s})$ which were evaluated for repeatability. These steps were repeated until the $\mathrm{CV}$ response was consistent across three slow cycles.

$\mathrm{CO}$ tolerance was evaluated using a range of electrochemical techniques to determine key catalyst characteristics; $\mathrm{CO}$ oxidation onset potential, ECSA, and the relative rate of $\mathrm{CO}$ oxidation at given potentials. $\mathrm{CO}$ oxidation onset potential was evaluated using a modified CO-stripping voltammetry technique ${ }^{20,22}$ whereby hydrogen is used to amplify the current response following oxidation of $\mathrm{CO}$ (hereafter referred to as " $\mathrm{H}_{2}-\mathrm{CO}$ stripping"); an improvement on the widely used CO stripping technique performed in an inert nitrogen (or argon) atmosphere (hereafter reffered to as " $\mathrm{N}_{2}-\mathrm{CO}$ stripping"). A monolayer of $\mathrm{CO}$ is adsorbed onto the surface of the catalyst whilst holding the potential at $\sim 0 \mathrm{~V}_{\mathrm{RHE}}$ and, under electrode rotation of $400 \mathrm{rpm}$, the potential is increased until $\mathrm{CO}$ oxidation occurs; in saturating the electrolyte with $\mathrm{H}_{2}$ we provide a readily available fuel for oxidation which gives a large and immediate current response upon liberation of Pt catalytic sites. The relative rate of CO oxidation at low potentials was evaluated using a chronoamperometric method; a $\mathrm{CO}$ monolayer was adsorbed on the surface of the catalyst at $0 \mathrm{~V}_{\mathrm{RHE}}$, the solution then purged with hydrogen or nitrogen, then the potential stepped to a given value $\left(0.1 \mathrm{~V}_{\mathrm{RHE}}\right)$ and the current response measured.

\subsubsection{ECSA Determination}

ECSA was determined via copper-stripping (Cu-stripping) voltammetry ${ }^{25}$; a monolayer of $\mathrm{Cu}$ atoms was deposited on the catalyst surface from a $\mathrm{Cu}^{2+}$ solution by applying a potential of $0.3 \mathrm{~V}_{\mathrm{RHE}}$ for $100 \mathrm{~s}$, and subsequently stripped anodically by sweeping the potential up to $1.4 \mathrm{~V}_{\mathrm{RHE}}$ at $10 \mathrm{mV} / \mathrm{s}$, with the corresponding charge used to determine the Pt surface area, assuming $420 \mu \mathrm{C} / \mathrm{cm}^{2}{ }^{26}$. Quoted ECSA values for catalysts are average values taken from three or more measurements, with errors calculated from the range relative to the average. The absence of any interaction between copper ions and $\mathrm{WO}_{3}$, carbon, or the $\mathrm{GC}$ electrode was confirmed via $\mathrm{Cu}$-ECSA measurements with these components in the absence of platinum (Figure S1).

\subsubsection{In situ ATR-IR Spectroscopy}

ATR-IR measurements were performed using a Thermo Nicolet iS50 spectrometer equipped with a liquid nitrogen cooled mercury cadmium telluride (MCT) detector and a Veemax III ATR accessory (Pike Technologies) set to an incidence angle of $60^{\circ}$. Incident light was polarized at $90^{\circ}$ using a built-in polarizer. Spectroelectrochemical measurements were performed using a modified Pike Technologies electrochemical ATR cell, a schematic depiction of which is shown in Figure 1. A mercury/mercurous sulphate electrode $(E=0.69 \mathrm{~V}$ $v s$ RHE) was used as a reference electrode and a gold wire was employed as a counter electrode. Au thin-film working electrodes were deposited onto a $20 \mathrm{~mm}$ diameter silicon internal reflection element (IRE, bevelled at $60^{\circ}$, PIKE Technologies) according to the following procedure: (i) the IRE was first cleaned by immersion in aqua regia $\left(3 \mathrm{HCl}: 1 \mathrm{HNO}_{3}\right.$ ) followed by sequential ultrasonication in water, isopropyl alcohol and acetone; (ii) the IRE was dried in an oven for at least an hour at $120^{\circ} \mathrm{C}$; (iii) the IRE was inserted into a custom-built holder before placing into a Quorum Q150 T turbo-pumped sputter coater; (iv) a $10 \mathrm{~nm}$ layer of Au was then deposited at a rate of approximately $13 \mathrm{~nm} / \mathrm{min}$. Catalyst samples were deposited onto the working electrode by drop casting $40 \mu \mathrm{L}$ of ink 1 or 2 (section 2.1) directly onto the gold-coated IRE followed by heating in an oven for at least an hour at $120^{\circ} \mathrm{C}$. The sample-coated IRE was mounted into the electrochemical cell, which was then filled with $0.1 \mathrm{M}$ $\mathrm{H}_{2} \mathrm{SO}_{4}$ and deaerated with a flow of Ar gas for 20 min. 
Catalyst films were initially electrochemically activated by performing cyclic voltammetry between 0 and 1.3 $\mathrm{V}_{\text {RHE }}$ and the potential was then held at $0.02 \mathrm{~V}_{\text {RHE }}$ whilst the initial background ATR-IR spectrum was recorded. Spectra were recorded with a resolution of $4 \mathrm{~cm}^{-1}$ and were typically averaged over 256 acquisitions (total acquisition time $\sim 2 \min 40 \mathrm{~s}$ ). The solution was then dosed with a flow of pure CO gas for 10 minutes, whilst maintaining a potential of $0.02 \mathrm{~V}_{\mathrm{RHE}}$, and periodic spectra were recorded to ensure the solution and sample surface were fully saturated (as indicated by an unchanging spectrum over time). The solution was then purged using a flow of Ar gas for 30 minutes, again ensuring the ATR-IR spectrum was completely stable after this time. The working electrode bias was then stepped to incrementally higher potentials and fixed at each new potential value whilst an ATR-IR spectrum was recorded, allowing $5 \mathrm{~s}$ for initial equilibration.

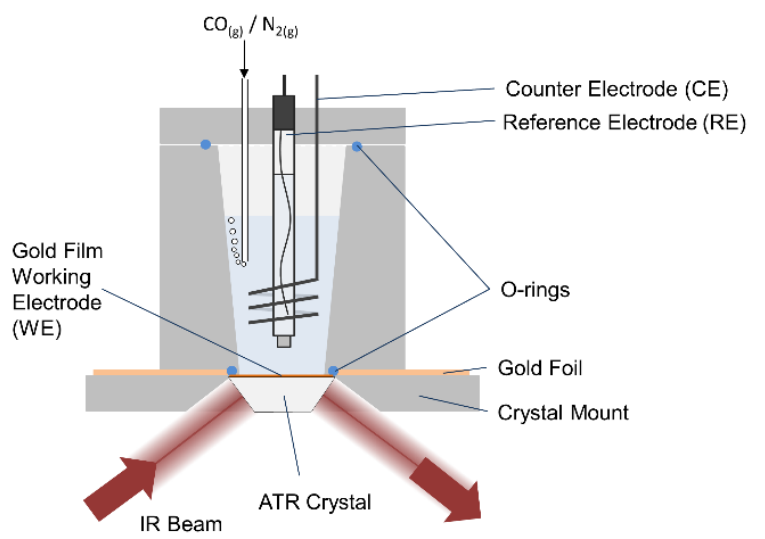

Figure 1 | Schematic Depiction of ATR-IR Electrochemical Setup.

\subsubsection{In situ Raman Spectroscopy}

Raman spectra were measured during cyclic voltammetry in situ using a dedicated 3-electrode spectroelectrochemical Raman cell (Redoxme, Sweden) comprising a quartz window $3 \mathrm{~mm}$ above a glassy carbon working electrode, a $\mathrm{Ag} / \mathrm{AgCl}$ reference electrode and a Pt wire counter electrode. A $532 \mathrm{~nm}$ laser was employed, using $25 \%$ power (approx. $4 \mathrm{~mW}$ ), a 600 lines/mm grating and a 50× SLWD objective lens. $200 \times 1 \mathrm{~s}$ acquisitions were performed for each measurement, using a beam rastering tool to increase the spot diameter to $20 \mu \mathrm{m}$ and avoid sample damage. The laser was focussed on the sample surface prior to each measurement and all spectra recorded using the same instrument parameters to allow qualitative comparison of relative intensities.

Electrode inks were cast on a glassy carbon working electrode and dried in air. After insertion of the working electrode, the cell was then filled with a solution of $0.1 \mathrm{M} \mathrm{H}_{2} \mathrm{SO}_{4}$ and sealed. An initial potential of $0 \mathrm{~V}_{\mathrm{RHE}}$ was applied for $30 \mathrm{mins}$, after which the potential was stepped to the target value and held for 10 mins prior to a spectrum being recorded.

Peaks were fitted to Lorentzian lineshapes and are reported \pm the standard error associated with the fitting. Peak areas are reported as the integrated area of the spectra between $790 \mathrm{~cm}^{-1}$ and $837 \mathrm{~cm}^{-1}$, with background subtraction. 


\section{Results}

\subsection{Catalyst Structure}

The as-synthesised $\mathrm{WO}_{3}$ nanoplatelets averaged $\sim 100 \mathrm{~nm}$ in diameter (Figure 2a), with XRD analysis confirming a monoclinic crystal structure (Figure S2). TEM analysis confirmed $\sim 5 \mathrm{~nm}$ average Pt particle size for the Tanaka Pt/C catalyst (Figure 2b). HR-SEM images show reasonable inter-dispersion of $\mathrm{Pt} / \mathrm{C}$ and $\mathrm{WO}_{3}$ components in the mixed catalyst electrodes (Figure 2c,d); the $\mathrm{WO}_{3}$ nanoplatelets do have a tendency to "stack" although this was considered unavoidable without surface modification.

XPS analysis indicates a $\sim 0.2 \mathrm{eV}$ shift in the $\mathrm{Pt}_{4 \mathrm{f}}$ electron peak position to lower binding energy for the $\mathrm{Pt} / \mathrm{C} / \mathrm{WO}_{3}$ catalyst mixture compared to pure $\mathrm{Pt} / \mathrm{C}$. Whilst this difference is very small, it was found to be repeatable and does align with previous work on $\mathrm{WO}_{3}$-supported $\mathrm{Pt}\left(\mathrm{Pt} / \mathrm{WO}_{3}\right)$ catalysts ${ }^{14}$. It is interesting that a similar magnitude shift in binding energy has been measured for this catalyst mixture, given there is no direct "bonding" between the Pt and $\mathrm{WO}_{3}$ components, as there was in the case of Maillard et al. ${ }^{14}$ Clearly the observed shift in our case is not an SMSI in the formal sense, since the $\mathrm{WO}_{3}$ component here is not used as a support, but the effect appears to be similar. These observations would suggest either a substantial two-phase boundary between $\mathrm{Pt}$ and $\mathrm{WO}_{3}$ across the sample in our physical mixture or an equilibration of the electronic energy levels mediated by the conducting carbon support.
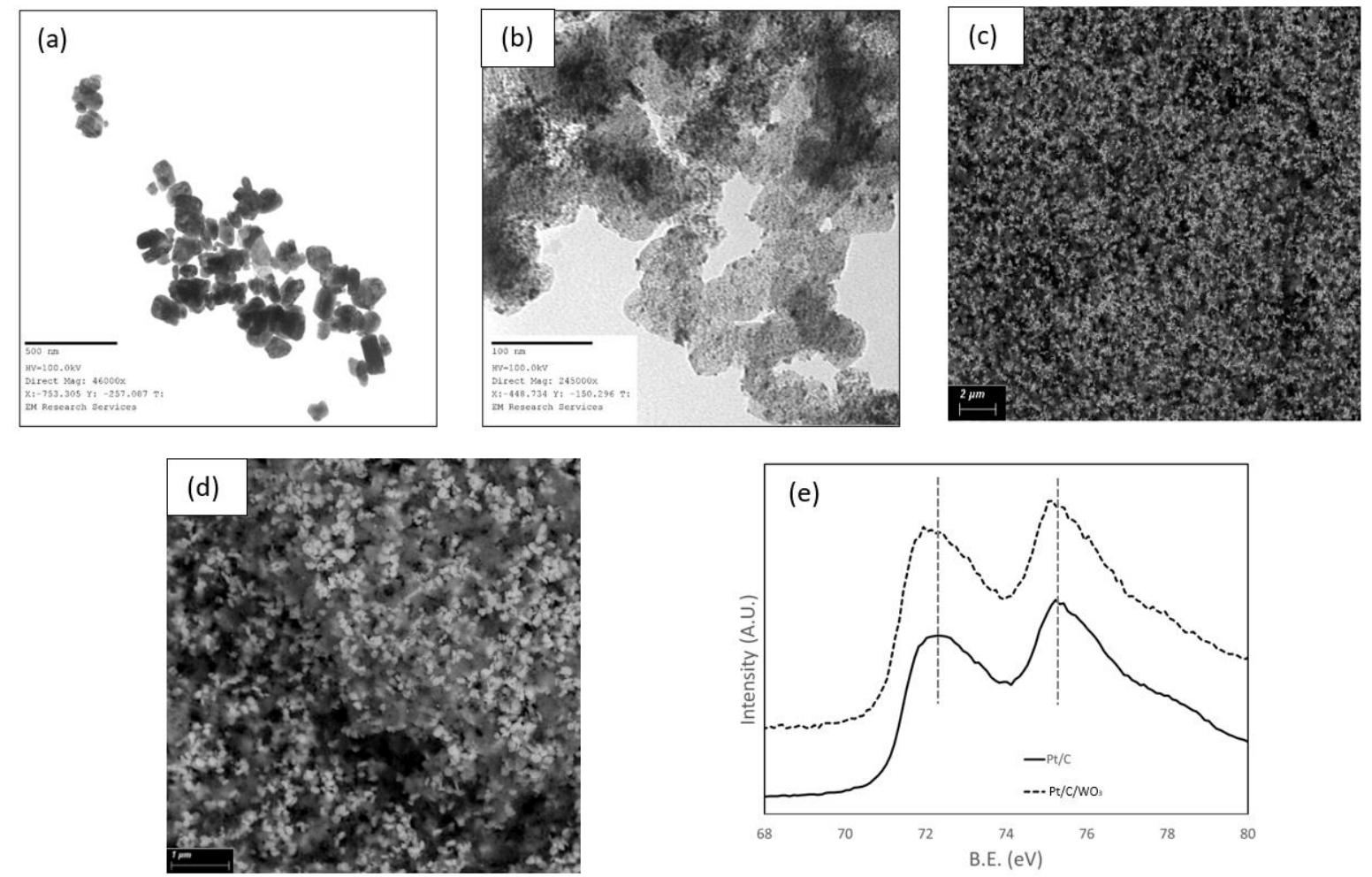

Figure 2 | Structural analysis of catalysts: (a) TEM image of $\mathrm{WO}_{3}$ nanoparticles, as synthesised; (b) TEM image of Pt/C catalyst (Tanaka); (c,d) HR-SEM images of a Pt/C/WO 3 electrode surface; (e) $\mathrm{Pt}_{4 \mathrm{f}}$ electron XPS spectra for $\mathrm{Pt} / \mathrm{C}$ and $\mathrm{Pt} / \mathrm{C} / \mathrm{WO}_{3}$ electrodes.

Given the platinum-tungsten interaction shown in the XPS data, we should address the possibility of W soluble species depositing on the platinum surface during measurements. Reichman and reported that both single crystal and polycrystalline $\mathrm{WO}_{3}$ electrodes show high stability toward dissolution in aqueous acid solutions under open-circuit conditions and when the potential is cycled in the electrochromic region (where only very small currents flow) ${ }^{27}$. This region represents the reversible and partial reduction of $\mathrm{WO}_{3}$ (hydrogen tungsten bronze formation) by proton intercalation, similar to the conditions of our study. The bronze structure may be considered to have a water content, which is linked to increased solubility, but Lillard et al. state that dissolution is limited by the mass transport of a loosely bound $\mathrm{WO}_{3}\left(\mathrm{H}_{2} \mathrm{O}\right)_{\mathrm{x}}$ layer from the electrode surface ${ }^{28}$. 


\subsection{Electrochemistry}

Cyclic voltammetry in the supporting electrolyte of all catalysts and the GC electrode can be found in the supplementary information (Figure S4). These CVs confirm the Pt surface is clean and free of contaminants, and as expected, the addition of $\mathrm{WO}_{3}$ to the $\mathrm{Pt} / \mathrm{C}$ electrode results in changes to the $\mathrm{H}_{\text {UPD }}$ region $\left(\mathrm{E}<0.3 \mathrm{~V}_{\mathrm{RHE}}\right)$ without any noticeable impact on the Pt-oxide region $\left(\mathrm{E}>0.5 \mathrm{~V}_{\mathrm{RHE}}\right)$.

\subsubsection{ECSA}

ECSA measurements (Table 1) were performed using the $\mathrm{Cu}$ stripping method and show that there is no significant difference in ECSA between $\mathrm{Pt} / \mathrm{C}$ and $\mathrm{Pt} / \mathrm{C} / \mathrm{WO}_{3}$, demonstrating that the addition of $\mathrm{WO}_{3}$ does not have a negative impact on Pt surface area available for catalysis.

Typical methods for determination of the electrochemical surface area of Pt-based catalysts involve integration of the charge associated with either hydrogen underpotential deposition $\left(\mathrm{H}_{\mathrm{UPD}}\right){ }^{23}$ or oxidation of $\mathrm{CO}$ ${ }^{24}$. For $\mathrm{WO}_{3}$-containing catalysts the $\mathrm{H}_{\text {UPD }}$ method is unsuitable due to the overlap with the $\mathrm{W}^{5+} / \mathrm{W}^{6+}$ region, and since $\mathrm{Pt} \mid \mathrm{WO}_{3}$ catalysts have been shown to oxidise $\mathrm{CO}$ in the $\sim 0.1 \mathrm{~V}_{\mathrm{RHE}}$ region, integration of any $\mathrm{CO}$ oxidation charge in the $0.6-0.9 \mathrm{~V}_{\mathrm{RHE}}$ region is likely to be inaccurate. ECSA values for the Pt/C catalyst calculated via the three most prevalent methods ( $\mathrm{H}_{\mathrm{UPD}}, \mathrm{CO}$ stripping and $\mathrm{Cu}$ stripping) are consistent $\left(58,60\right.$ and $61 \mathrm{~m}^{2} / \mathrm{g}_{\mathrm{Pt}}$ respectively) confirming the reliability of ECSA measurements using the $\mathrm{Cu}$ stripping method.

\begin{tabular}{c|c} 
Catalyst & $\mathbf{C u}-\mathbf{E C S A}\left(\mathbf{m}^{2} / \mathbf{g}_{\mathbf{P t}}\right)$ \\
\hline $\mathbf{P t} / \mathbf{C}$ & $60.6 \pm 1.2$ \\
\hline $\mathbf{P t} / \mathbf{C} / \mathbf{W O} \mathbf{O}_{3}$ & $61.7 \pm 0.4$ \\
Table $1 \mid \mathrm{ECSA}$ of $\mathrm{Pt} / \mathrm{C}$ and $\mathrm{Pt} / \mathrm{C}_{\mathrm{W} O}$ catalysts measured using Cu-stripping.
\end{tabular}

\subsubsection{CO Stripping Voltammetry}

Figure 3a depicts linear sweep voltammetry of $\mathrm{Pt} / \mathrm{C}$ performed using the $\mathrm{H}_{2}$ - $\mathrm{CO}$ stripping method (see Section 2.3). While $\mathrm{CO}$ is oxidised on mono-crystalline Pt electrodes at $\sim 0.7 \mathrm{~V}_{\mathrm{RHE}}$ (a potential determined by the formation of $\mathrm{Pt}-\mathrm{OH}$ groups on bulk $\mathrm{Pt}$ ), $\mathrm{CO}$ stripping voltammetry on nanoparticulate $\mathrm{Pt} / \mathrm{C}$ catalysts has been shown to exhibit a "pre-peak" in the range $0.4-0.7 \mathrm{~V}_{\mathrm{RHE}}$. Using the $\mathrm{H}_{2}-\mathrm{CO}$ stripping measurement we clearly observe $\mathrm{CO}$ oxidation starting at $\sim 0.4 \mathrm{~V}_{\mathrm{RHE}}$, which is not immediately obvious from the $\mathrm{N}_{2}$-CO stripping data, unless one magnifies the plot (Figure 3a, inset). 
a)

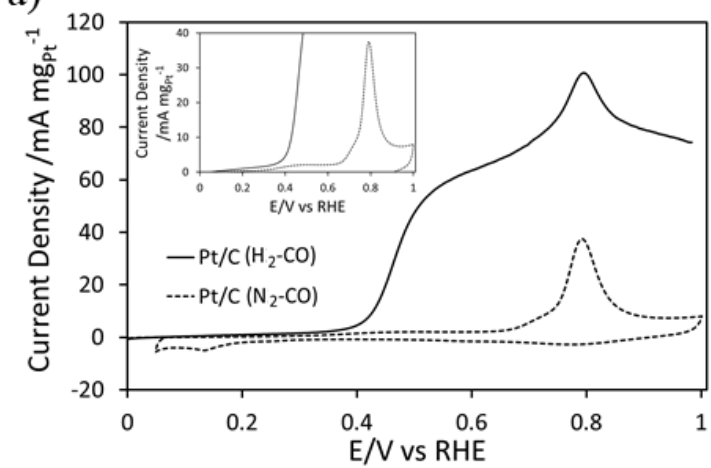

b)

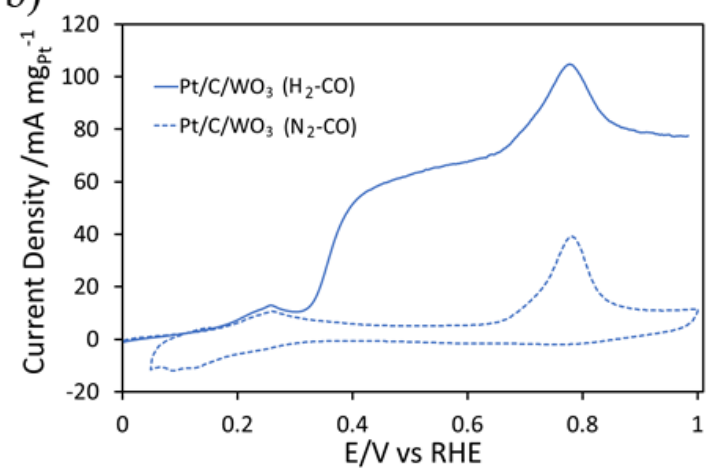

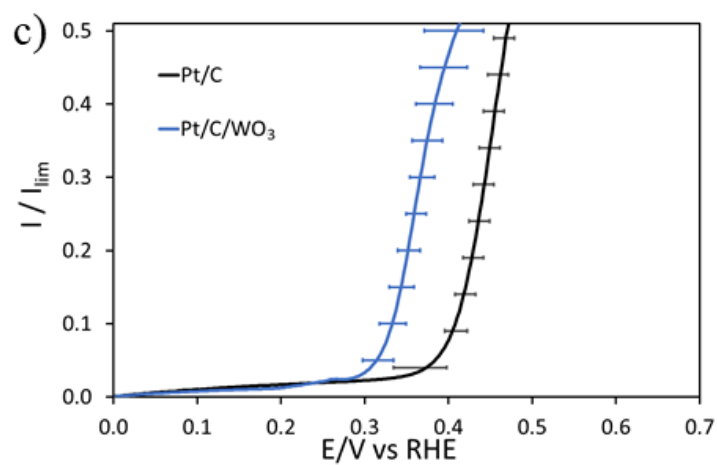

Figure $3 \mid \mathrm{N}_{2}$ - and $\mathrm{H}_{2}-\mathrm{CO}$ stripping voltammograms of (a) $\mathrm{Pt} / \mathrm{C}$ and (b) $\mathrm{Pt} / \mathrm{C} / \mathrm{WO}_{3}$ catalysts, recorded at $10 \mathrm{mV} / \mathrm{s}$ and 400 $\mathrm{rpm}$. The inset of (a) depicts the same data magnified over a lower current range; (c) Difference voltammograms of the $\mathrm{N}_{2}-$ $\mathrm{CO}$ stripping voltammogram subtracted from the $\mathrm{H}_{2}-\mathrm{CO}$ voltammogram for $\mathrm{Pt} / \mathrm{C}$ and $\mathrm{Pt} / \mathrm{C} / \mathrm{WO}_{3}$.

The $\mathrm{H}_{2}$-CO stripping measurement technique also provides clarity in the evaluation of $\mathrm{WO}_{\mathrm{x}}$-containing catalysts; tungsten oxide-platinum catalysts have demonstrated $\mathrm{CO}$ oxidation in the $<0.3 \mathrm{~V}_{\mathrm{RHE}}$ region ${ }^{14,19}$, which overlaps the $\mathrm{W}^{\mathrm{V} / \mathrm{VI}}$ redox couple. The reduction and oxidation of tungsten oxides in an acidic environment is accompanied by the intercalation and de-intercalation of protons to form tungsten bronze species, which produces a current response that can obscure other processes (equation 3).

$$
\mathrm{WO}_{3}+x \mathrm{e}^{-}+x \mathrm{H}^{+} \rightleftharpoons \mathrm{H}_{x} \mathrm{~W}_{x}^{\mathrm{V}} \mathrm{W}_{1-x}^{\mathrm{VI}} \mathrm{O}_{3}
$$

Figure $3 \mathrm{~b}$ shows the stripping voltammetry for the $\mathrm{Pt} / \mathrm{C} / \mathrm{WO}_{3}$ physical mixture catalyst, from which we observe a distinctive peak in both $\mathrm{H}_{2}-\mathrm{CO}$ and $\mathrm{N}_{2}-\mathrm{CO}$ voltammograms at just below $\sim 0.3 \mathrm{~V}_{\mathrm{RHE}}$, which we attribute to the oxidation of the $\mathrm{W}^{\mathrm{V}}$ tungsten bronze to $\mathrm{W}^{\mathrm{VI}}$ (a potential which is in agreement with the literature ${ }^{29}$ ).

By utilising both the $\mathrm{H}_{2}-\mathrm{CO}$ stripping and $\mathrm{N}_{2}$-CO stripping measurements, we can subtract the extraneous current resulting from $\mathrm{CO}$ oxidation and the tungsten bronze redox electrochemistry detailed in equation 3 , leaving only hydrogen oxidation current (Figure 3c), the onset potential of which equates to the onset potential of CO oxidation. From Figure $3 \mathrm{c}$ it is clear that the onset of $\mathrm{CO}$ oxidation is shifted negatively by $\sim 100 \mathrm{mV}$ when $\mathrm{WO}_{3}$ is added to the $\mathrm{Pt} / \mathrm{C}$ catalyst and a small step appears prior to the main hydrogen oxidation current onset $(\sim 0.27$ $0.3 \mathrm{~V}_{\mathrm{RHE}}$ ). We have confirmed that this $\sim 100 \mathrm{mV}$ shift is not due to hydrogen oxidation directly on the $\mathrm{WO}_{3}$ component (Figure S3). We note from Figure $3 \mathrm{a}$ and $\mathrm{b}$ that there is no apparent change in the onset or peak potential of the characteristic high-potential Pt-CO oxidation peak ( $\left.\sim .8 \mathrm{~V}_{\mathrm{RHE}}\right)$, indicating, in agreement with Brkovic et al. ${ }^{21}$, that a significant proportion of the Pt surface is unaffected by the presence of $\mathrm{WO}_{3}$ on the timescale of these potentiodynamic measurements. At this point we should also note the relatively small proportion of Pt sites that are required to drive the reaction to diffusion control, given the high activity of Pt for hydrogen oxidation. We have not attempted to calculate the exact mass of platinum required to achieve diffusion control in these experiments, however groups working with electrodes of similar loading agree that the value is between 5 and $10 \%{ }^{14}$. 


\subsubsection{Chronoamperometry}

Figure 4 shows the result of chronoamperometry in $\mathrm{H}_{2}$-purged electrolyte of $\mathrm{Pt} / \mathrm{C}$ and $\mathrm{Pt} / \mathrm{C} / \mathrm{WO}_{3}$ electrodes that were first covered with a $\mathrm{CO}$ monolayer at $0 \mathrm{~V}_{\mathrm{RHE}}$. For $\mathrm{Pt} / \mathrm{C} / \mathrm{WO}_{3}$, stepping the potential to $0.1 \mathrm{~V}_{\mathrm{RHE}}$ results in measurable $\mathrm{H}_{2}$-oxidation current after $\sim 600 \mathrm{~s}$, whilst negligible currents are observed for $\mathrm{Pt} / \mathrm{C}$. This result is in agreement with a similar experiment conducted by Maillard et al. ${ }^{14} \mathrm{We}$ suggest this evolution of hydrogen oxidation current over time reflects relatively slow $\mathrm{CO}$ oxidation kinetics at this potential, given that after 30 minutes the maximum current achieved equates to $\sim 70 \%$ of the diffusion-limited current. We stress that this is unlikely to be the result of $\mathrm{CO}$ desorption given $\mathrm{Pt} / \mathrm{C}$ exhibits no $\mathrm{H}_{2}$-oxidation current in the equivalent measurement.

We note that the data presented in Figure 4 is apparently contrary to our observations in the $\mathrm{H}_{2}-\mathrm{CO}$ stripping voltammetry in which the lack of $\mathrm{H}_{2}$-oxidation current at $<0.3 \mathrm{~V}_{\mathrm{RHE}}$ suggests no $\mathrm{CO}$ oxidation occurs in this potential region. An explanation for this apparent discrepancy lies in the timescale of the measurement; we propose that $\mathrm{CO}$ oxidation does occur in this low potential region and can be observed on the 10 minute timescale of the chronoamperometry measurement, however the rate is too low for the associated current to be resolved on a cyclic voltammogram (with a timescale in the order of seconds).

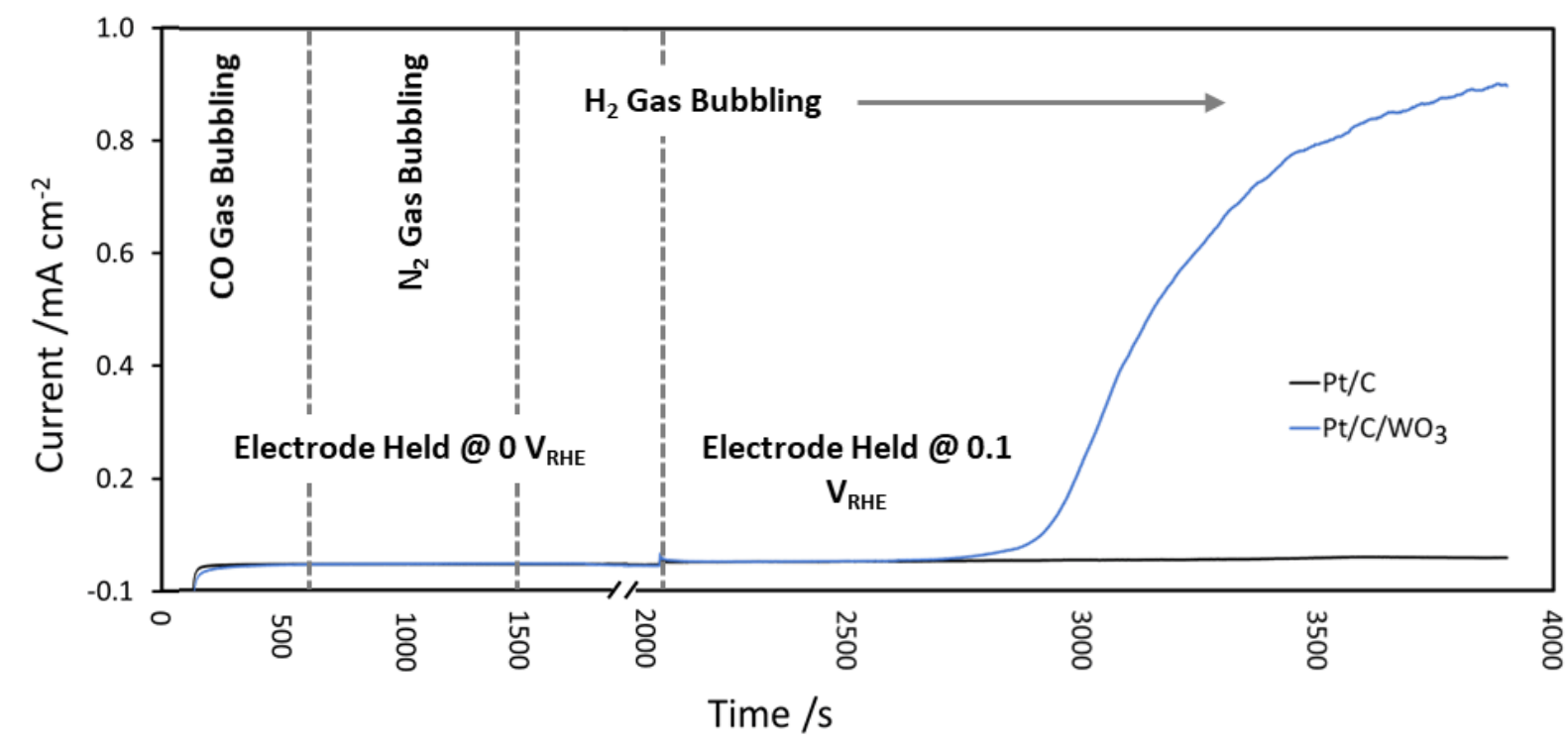

Figure 4 | Chronoamperometry at $0.1 \mathrm{~V}$ RHE of $\mathrm{Pt} / \mathrm{C}$ and $\mathrm{Pt} / \mathrm{C} / \mathrm{WO}_{3}$ following $\mathrm{CO}$ adsorption at $0 \mathrm{~V}_{\mathrm{RHE}}$. Electrode under rotation at $400 \mathrm{rpm}$.

\subsection{Spectroelectrochemistry}

\subsubsection{In situ Raman Spectroscopy}

The voltammetry presented in Figure $3 \mathrm{~b}$ exhibits a pair of redox peaks centred at approximately $0.2 \mathrm{~V}_{\mathrm{RHE}}$ that we attribute to the $\mathrm{W}^{\mathrm{V} / \mathrm{VI}}$ redox couple. In order to probe the oxidation state of the tungsten oxide at different potentials and to better understand its possible influence on the improved $\mathrm{CO}$ tolerance of $\mathrm{Pt} / \mathrm{C} / \mathrm{WO}_{3}$ catalysts, in situ Raman spectroscopy was performed, and the results are presented in Figure 5. Raman spectroscopy typically probes material within up to $1 \mu \mathrm{m}$ of the surface, and therefore in the case of the $\mathrm{WO}_{3}$ nanoparticles studied here the Raman spectra can be considered representative of the bulk material at each potential. The in situ spectrum at open circuit potential (approx. $0.95 \mathrm{~V}$ RHE) of the $\mathrm{Pt} / \mathrm{C} / \mathrm{WO}_{3}$ electrode exhibits three peaks at 271, 714 and 807 $\mathrm{cm}^{-1}$, assigned to a $\delta(\mathrm{O}-\mathrm{W}-\mathrm{O})$ bending mode and two W-O stretching modes, respectively, of $\mathrm{WO}_{3}{ }^{30}$. Upon application of a reducing potential of $0 \mathrm{~V}_{\mathrm{RHE}}$ for 30 mins, these peaks vanish. This is consistent with previous reports ${ }^{30}$, where the in situ electrochemical generation of hydrogenated tungsten bronzes $\left(\mathrm{H}_{x} \mathrm{WO}_{3}\right.$ where $\left.x>0.25\right)$ with a tetragonal phase also resulted in the disappearance of these modes. Upon application of a more positive potential of $0.1 \mathrm{~V}_{\mathrm{RHE}}$, one peak at $820 \mathrm{~cm}^{-1}$ is observed, and a similar spectrum is retained at potentials up to and including $0.25 \mathrm{~V}_{\mathrm{RHE}}$. This species is assigned as $\mathrm{H}_{x} \mathrm{WO}_{3}$ where $0<x<0.25$, based on comparison with literature spectra ${ }^{30,31}$, and therefore in this potential range up to $25 \%$ of the tungsten centres are reduced to $\mathrm{W}^{\mathrm{V}}$. Finally, at 
potentials of $0.3 \mathrm{~V}_{\mathrm{RHE}}$ and above, the $820 \mathrm{~cm}^{-1}$ peak shifts to $807 \mathrm{~cm}^{-1}$ and the $271 \mathrm{~cm}^{-1}$ and $714 \mathrm{~cm}^{-1}$ peaks reemerge, indicating fully oxidised, monoclinic $\mathrm{WO}_{3}\left(\mathrm{~W}^{\mathrm{VI}}\right)$.
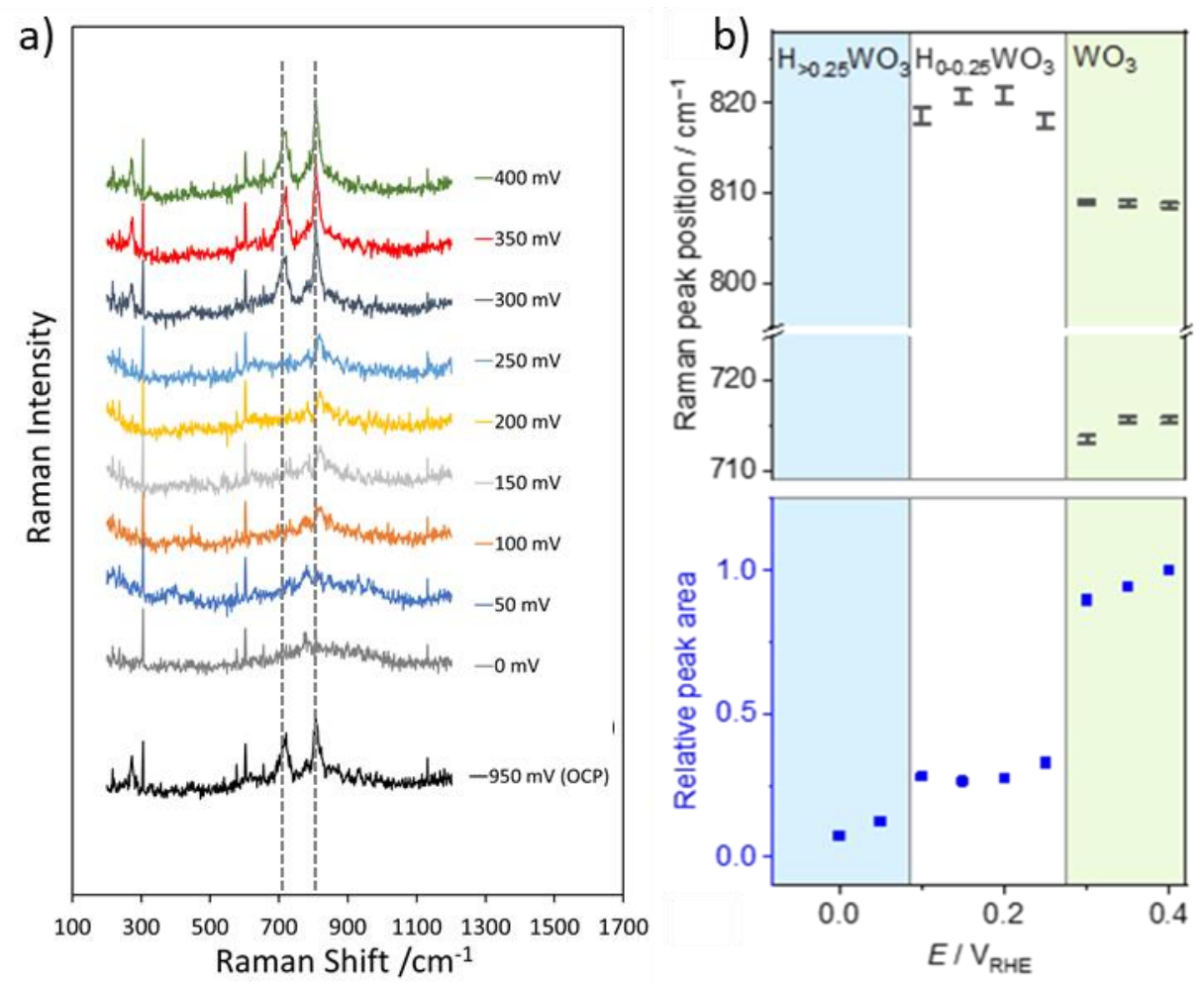

Figure 5 | (a) In situ Raman spectroscopy of $\mathrm{Pt} / \mathrm{C} / \mathrm{WO}_{3}$ electrodes in $0.1 \mathrm{M} \mathrm{H}_{2} \mathrm{SO}_{4}$ solution. (b) Peak positions and integrated areas of the peak at $\sim 810 \mathrm{~cm}^{-1}$ from the in-situ spectra in (a).

The spectral changes associated with the above phase transitions appear to occur in discrete steps, rather than on a continuum. This is illustrated in Figure 5b, in which the band positions of the W-O stretching peaks and the integrated area of the peak above $800 \mathrm{~cm}^{-1}$, normalised to the maximum value are plotted as a function of applied potential (the signal intensity below $0.3 \mathrm{~V}_{\text {RHE }}$ was too weak to confidently assign a peak position). In both cases, three clear regimes are observed, corresponding to the above assignments. The shift in peak position to higher wavenumber at lower potential is indicative of a stronger $\mathrm{W}-\mathrm{O}$ bond in the hydrogenated tungsten bronze than in $\mathrm{WO}_{3}$, explained by the increased covalency of $\mathrm{W}^{\mathrm{V}}-\mathrm{O}$ bonds compared to $\mathrm{W}^{\mathrm{VI}}-\mathrm{O}$ bonds ${ }^{31}$, and may facilitate the increased $\mathrm{CO}$ oxidation activity at more positive potentials (see discussion). The decreased peak area of the more hydrogenated tungsten bronzes is explained by increased colouration of the reduced sample, lowering the amount of scattered light ${ }^{31}$, as well as the lower optical skin depth of more conducting materials such as tungsten bronzes compared to semiconducting $\mathrm{WO}_{3}{ }^{32}$. The comparison of peak areas is thus not quantitative but gives a strong indication of the distinct phases present at different potentials.

Taken together, the in situ Raman spectroscopy measurements suggest the presence of three potential domains in which different tungsten oxidation states dominate, with up to $25 \%$ of tungsten centres in the $\mathrm{W}^{\mathrm{V}}$ oxidation state in the 0.1 to $0.3 \mathrm{~V}_{\mathrm{RHE}}$ window in the $\mathrm{Pt} / \mathrm{C} / \mathrm{WO}_{3}$ system, and fully-oxidised $\mathrm{W}^{\mathrm{VI}}$ at potentials of 0.3 $\mathrm{V}_{\mathrm{RHE}}$ and above, as listed below.

$$
\begin{array}{rll}
E<0.1 V_{R H E} & \mid & \mathrm{H}_{>0.25} \mathrm{WO}_{3} \\
0.1 \leq E<0.3 V_{R H E} & \mid & \mathrm{H}_{0-0.25} \mathrm{WO}_{3} \\
E \geq 0.3 V_{R H E} & \mid & \mathrm{WO}_{3}
\end{array}
$$


Finally, it is well-established that $\mathrm{Pt}$ can induce oxidation state changes in $\mathrm{WO}_{3}$ in the presence of water at room temperature through $\mathrm{H}_{2}$ spillover ${ }^{33,34}$. It should be noted that the experiments described here were performed on the $\mathrm{Pt} / \mathrm{C} / \mathrm{WO}_{3}$ system, and therefore that any effect of $\mathrm{Pt}$ on the oxidation state of $\mathrm{WO}_{3}$ is manifested in the spectra presented, which are thus directly applicable to the electrochemical system under consideration.

\subsubsection{In situ ATR-IR Spectroscopy}

The $\mathrm{CO}$ oxidation behaviour of $\mathrm{Pt} / \mathrm{C}$ catalysts in the absence and presence of $\mathrm{WO}_{3}$ was studied using in situ ATR-IR spectroscopy, a very powerful tool for studying Pt-CO interactions. Figure 6a depicts a sequence of ATRIR spectra recorded for the Pt/C catalyst in Ar-purged $0.1 \mathrm{M} \mathrm{H}_{2} \mathrm{SO}_{4}$ after $\mathrm{CO}$ adsorption from a CO-saturated solution. The spectra exhibit typical features of a Pt-CO surface, with bands in the ranges $2000-2100 \mathrm{~cm}^{-1}$ and $1820-1920 \mathrm{~cm}^{-1}$ attributed to the $\mathrm{C}-\mathrm{O}$ stretch of $\mathrm{CO}$ bound to $\mathrm{Pt}$ in a linear $\left(\mathrm{CO}_{\mathrm{L}}\right)$ and bridge-bonded $\left(\mathrm{CO}_{\mathrm{B}}\right)$ configuration, respectively.

At the initial potential of $0.04 \mathrm{~V}_{\text {RHE }}$ the linear $\mathrm{CO}$ band is relatively broad and asymmetric, with a peak at $2039 \mathrm{~cm}^{-1}$ and a shoulder at $2024 \mathrm{~cm}^{-1}$, reflecting multiple CO adsorption environments and heterogeneity across the catalyst surface. The band shape is qualitatively similar to that reported by Kunimatsu and co-workers ${ }^{35}$ for carbon-supported Pt catalysts, who attributed the primary peak to $\mathrm{CO}$ adsorption at Pt terrace sites, and the shoulder at lower wavenumbers to adsorption at step edge sites. As the substrate potential is stepped incrementally from $0.04 \mathrm{~V}_{\mathrm{RHE}}$ up to $1.09 \mathrm{~V}_{\mathrm{RHE}}$, both $\mathrm{CO}_{\mathrm{L}}$ and $\mathrm{CO}_{\mathrm{B}}$ bands shift towards higher wavenumbers and begin to decrease in intensity as $\mathrm{CO}$ is removed from the surface. We note that, in agreement with Kunimatsu et al. ${ }^{35}$, the shoulder at lower wavenumbers decreases continuously between $0 \mathrm{~V}_{\mathrm{RHE}}-0.4 \mathrm{~V}_{\mathrm{RHE}}$, whilst the primary peak remains relatively unchanged in this potential range, which may reflect the Pt surface structure sensitivity of the $\mathrm{CO}$ oxidation process. 

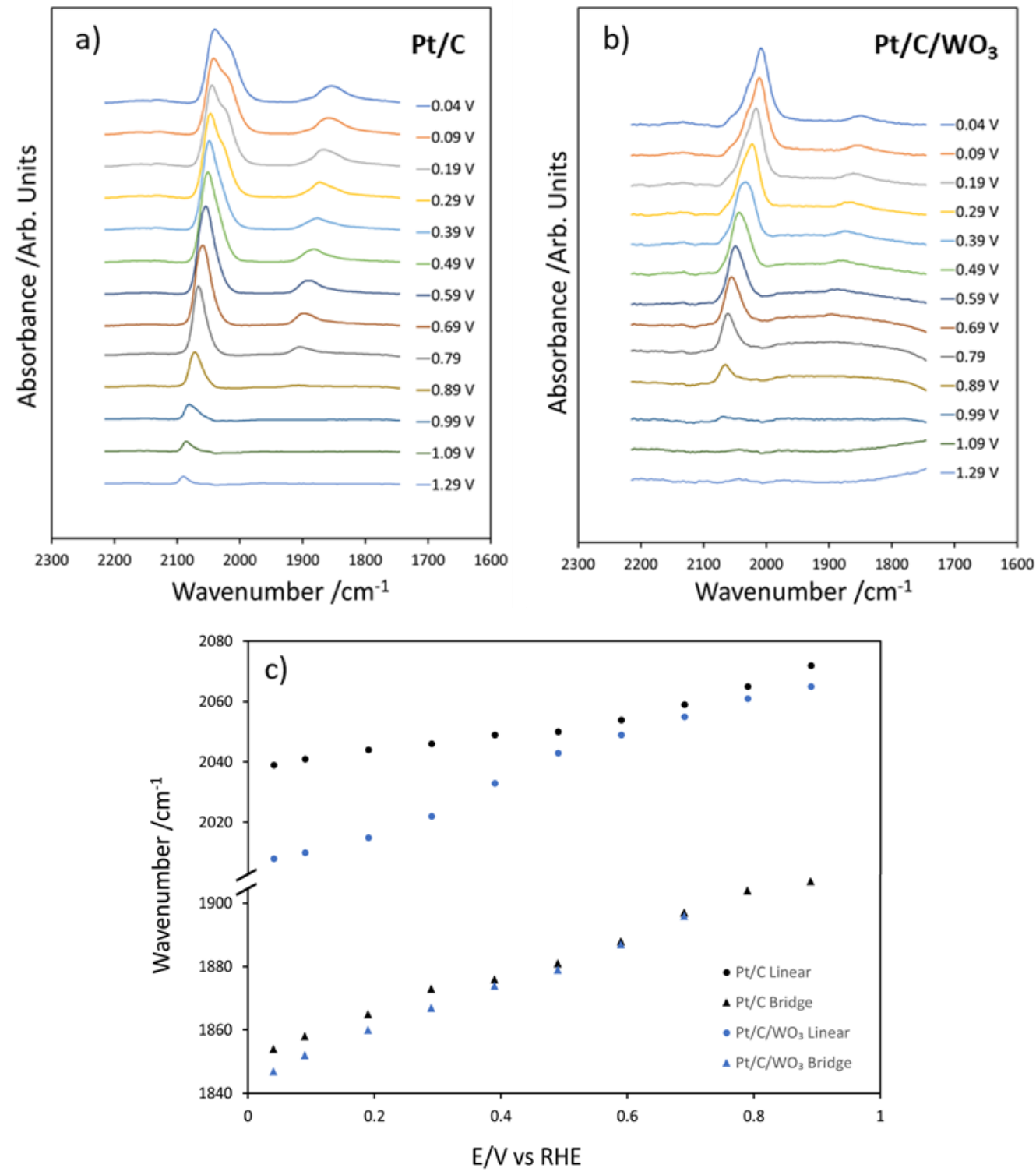

Figure 6 | ATR-IR spectra recorded in Ar-purged $0.1 \mathrm{M} \mathrm{H}_{2} \mathrm{SO}_{4}$ at a range of applied potentials for (a) Pt/C catalyst and (b) $\mathrm{Pt} / \mathrm{C} / \mathrm{WO}_{3}$ catalyst after adsorption of $\mathrm{CO}$. (c) Peak positions of linear and bridge-bound $\mathrm{CO}$ on $\mathrm{Pt} / \mathrm{C}$ (blue symbols) and $\mathrm{Pt} / \mathrm{C} / \mathrm{WO}_{3}$ (red symbols) catalysts plotted as a function of potential.

Broadly similar behaviour is observed for the $\mathrm{Pt} / \mathrm{C} / \mathrm{WO}_{3}$ catalyst (Figure $6 \mathrm{~b}$ ), although the shape and position of the linear bonded $\mathrm{CO}$ band at low potentials is rather different to $\mathrm{Pt} / \mathrm{C}$; in this case the primary peak appears at a lower wavenumber of $2009 \mathrm{~cm}^{-1}$, with two shoulders discernible at $2027 \mathrm{~cm}^{-1}$ and $2053 \mathrm{~cm}^{-1}$. The change in $\mathrm{CO}_{\mathrm{L}}$ band shape suggests a different distribution of adsorption sites and, in particular, the presence of a third distinct shoulder at high wavenumbers suggests that the presence of $\mathrm{WO}_{3}$ induces a new Pt-CO bonding environment. The fact that all of the $\mathrm{CO}$ bands in the $\mathrm{Pt} / \mathrm{C} / \mathrm{WO}_{3}$ catalyst appear at lower wavenumbers than for $\mathrm{Pt} / \mathrm{C}$ suggests an electronic/polarisation effect caused by $\mathrm{WO}_{3}$ and/or a reduced level of dipole-dipole coupling between adsorbed $\mathrm{CO}$ molecules, signifying a lower coverage or higher mobility; the relative contributions of these factors are discussed in more detail below. Since any electronic effect would be expected to vary with proximity and connectivity between Pt-CO and $\mathrm{WO}_{3}$, we speculate that these phenomena are responsible for the new bonding environment(s) observed. As with the $\mathrm{Pt} / \mathrm{C}$ catalyst, the $\mathrm{CO}_{\mathrm{L}}$ and $\mathrm{CO}_{\mathrm{B}}$ peak intensities decrease with increasing substrate potential, again with the lower wavenumber feature (in this case the peak at $2009 \mathrm{~cm}^{-1}$ ) being removed preferentially at lower potentials. 


\subsubsection{Variation in CO Band Position with Potential}

The quantitative variation of the $\mathrm{CO}_{\mathrm{L}}$ and $\mathrm{CO}_{\mathrm{B}}$ bands with potential is shown in Figure $6 \mathrm{c}$ for the $\mathrm{Pt} / \mathrm{C}$ and $\mathrm{Pt} / \mathrm{C} / \mathrm{WO}_{3}$ catalysts. Whilst multiple peaks contribute to the $\mathrm{CO}_{\mathrm{L}}$ band as discussed above, for simplicity only the position of the most prominent peak is plotted. Both the $\mathrm{CO}_{\mathrm{L}}$ and $\mathrm{CO}_{\mathrm{B}}$ bands exhibit a clear vibrational Stark effect, in which the peak position shifts to higher wavenumbers with increasing potential, reflecting the withdrawal of electron density from the Pt-C bond (i,e. reduced $\pi$-back-bonding from the Pt atom into the $\pi^{*}$ orbitals of the $\mathrm{CO}$ molecule). At potentials above approximately $0.6 \mathrm{~V}_{\mathrm{RHE}}$, the two catalysts exhibit similar behaviour, with linear Stark tuning rates of approximately $51 \mathrm{~cm}^{-1} / \mathrm{V}$ and $64 \mathrm{~cm}^{-1} / \mathrm{V}$ for $\mathrm{CO}_{\mathrm{L}}$ and $\mathrm{CO}_{\mathrm{B}}$ respectively. However, below $0.6 \mathrm{~V}_{\mathrm{RHE}}$ the $\mathrm{CO}_{\mathrm{L}}$ band positions diverge, leading to a lower $\mathrm{CO}_{\mathrm{L}}$ peak wavenumber in the presence of $\mathrm{WO}_{3}$, as discussed above.

The $\mathrm{CO}_{\mathrm{B}}$ band also appears at slightly lower wavenumbers in the $\mathrm{Pt} / \mathrm{C} / \mathrm{WO}_{3}$ catalyst, although the difference is substantially smaller than for the $\mathrm{CO}_{\mathrm{L}}$ band. The Stark tuning rates below $0.3 \mathrm{~V}_{\mathrm{RHE}}$ for $\mathrm{CO}_{\mathrm{L}}$ are approximately $25 \mathrm{~cm}^{-1} / \mathrm{V}$ and $55 \mathrm{~cm}^{-1} / \mathrm{V}$ for $\mathrm{Pt} / \mathrm{C}$ and $\mathrm{Pt} / \mathrm{C} / \mathrm{WO}_{3}$, respectively. The former is consistent with that previously reported for Pt/C catalysts ${ }^{36,37}$ whilst the latter is higher than expected. Abnormally high Stark tuning rates were previously attributed by Arenz et al. ${ }^{36}$ to the slow oxidation of $\mathrm{CO}$, which is consistent with the presence of $\mathrm{WO}_{3}$ imparting some improved $\mathrm{CO}$ tolerance at low potentials. $\mathrm{CO}$ oxidation may also explain the unusually high Stark tuning rates observed for both catalysts above $0.6 \mathrm{~V}_{\text {RHE }}$.

The lower wavenumber of the $\mathrm{CO}_{\mathrm{L}}$ band for $\mathrm{Pt} / \mathrm{C} / \mathrm{WO}_{3}$ compared to $\mathrm{Pt} / \mathrm{C}$ may be interpreted in two ways: (i) increased electron density on $\mathrm{Pt}$ due to the presence of $\mathrm{WO}_{3}$ could result in more back-donation into the $\pi^{*}$ orbital of the adsorbed $\mathrm{CO}$, thus lowering the $\mathrm{CO}$ vibrational wavenumber, consistent with the findings of Liu $e t$ al..$^{38}$ who studied CO adsorbed on Pt-Ru alloys; (ii) decreased dipole-dipole coupling ${ }^{39,40}$ between adjacent adsorbed $\mathrm{CO}$ molecules, resulting from a lower $\mathrm{CO}$ coverage and/or higher mobility as proposed by Igarashi et al. for $\mathrm{CO}$ oxidation on Pt-Fe alloys. ${ }^{7}$ Whilst both of these phenomena may contribute to the observed trend, we believe that our data favour (i) as the dominant effect for a number of reasons. Firstly, our XPS measurements suggest a reduced binding energy of $\mathrm{Pt}_{4 \mathrm{f}}$ electrons in the presence of $\mathrm{WO}_{3}$ (Figure 2e) which, although small, is consistent with an increase in back donation into the $\mathrm{CO} \pi^{*}$ orbital. By contrast, Igarashi et al. ${ }^{7}$ observed a small increase in $\mathrm{Pt}_{4 \mathrm{f}}$ binding energy and thus ruled out (i) on this basis. Secondly, the extent of the downshift in $\mathrm{CO}_{\mathrm{L}}$ wavenumber resulting from the presence of $\mathrm{WO}_{3}$ is approximately $40 \mathrm{~cm}^{-1}$ at the lowest potential. This is higher than the maximum shift typically attributed to dipole-dipole coupling effects (of the order of $30 \mathrm{~cm}^{-1}$ observed only when comparing the extremes of high and low coverages ${ }^{39}$ ), so for (ii) to be dominant, the $\mathrm{CO}$ coverage for $\mathrm{Pt} / \mathrm{C} / \mathrm{WO}_{3}$ at saturation would have to be drastically lower than for $\mathrm{Pt} / \mathrm{C}$, which is very unlikely based on our observations. Finally, data presented below on the ratio of linear to bridge bonded $\mathrm{CO}$ band intensities suggest a higher total saturation coverage of $\mathrm{CO}$ in the presence of $\mathrm{WO}_{3}$, which would be expected to lead to increased dipole interactions and would therefore not be consistent with a downshift in $\mathrm{CO}_{\mathrm{L}}$ wavenumber. We also considered the possibility that the electric field introduced by the presence of $\mathrm{WO}_{3}$ my impact the extent of dipoledipole coupling, for example by promoting the formation of compact $\mathrm{CO}$ islands, however this is unlikely given that the $\mathrm{CO}_{\mathrm{L}}$ wavenumber is generally lower in the presence of $\mathrm{WO}_{3}$.

Based on the above, the potential-dependant wavenumber shifts can be understood by considering the redox changes to the $\mathrm{WO}_{3}$. At low potentials $\left(E<0.3 \mathrm{~V}_{\mathrm{RHE}}\right.$ ) the $\mathrm{WO}_{3}$ is partially reduced and the resulting electron rich tungsten centres are able to donate electron density to $\mathrm{Pt}$, thus resulting in substantial back-donation and consequently a lower $\mathrm{CO}_{\mathrm{L}}$ wavenumber. At higher potentials $\left(E>0.3 \mathrm{~V}_{\mathrm{RHE}}\right)$ the $\mathrm{W}$ centres become fully oxidized so this electron donation becomes less pronounced, which is manifested as an upshift in the $\mathrm{CO}_{\mathrm{L}}$ wavenumber and a higher Stark shift.

A final issue worth considering in the context of the $\mathrm{CO}_{\mathrm{L}}$ wavenumber downshift is its implications regarding Pt-C bond strength. The increased Pt back-donation induced by $\mathrm{WO}_{3}$ may indicate a strengthening of the $\mathrm{Pt}-\mathrm{C}$ bond, which is naturally an important factor in understanding the apparent improvement in CO tolerance exhibited by $\mathrm{Pt} / \mathrm{C} / \mathrm{WO}_{3}$ catalysts. However, as pointed out by Wasileski and co-workers ${ }^{41}$, $\mathrm{CO}$ stretching frequency and metal-CO binding energy are not necessarily correlated, so at present the impact of $\mathrm{WO}_{3}$ on Pt-C bond strength remains ambiguous.

\subsubsection{Variation of CO Band Intensity with Potential}

To give an indication of the relative coverages of $\mathrm{CO}$, the variation in the integrated $\mathrm{CO}$ band intensity as a function of potential is plotted in Figure $7 \mathrm{a}$ and $\mathrm{b}$ for the $\mathrm{Pt} / \mathrm{C}$ and $\mathrm{Pt} / \mathrm{C} / \mathrm{WO}_{3}$ catalysts, respectively. To allow for variations in the absolute ATR-IR absorbance between samples, the $\mathrm{CO}_{\mathrm{L}}, \mathrm{CO}_{\mathrm{B}}$ and total $\mathrm{CO}$ intensities are 
normalised to the initial total $\mathrm{CO}$ signal intensity, recorded at $0.04 \mathrm{~V}_{\text {RHE. }}$ In both cases, the $\mathrm{CO}$ signal intensity decreases to zero as the applied potential is increased. Below we discuss the intensity variations in detail, and for clarity we split the data into three regions: low potentials $\left(E<0.3 \mathrm{~V}_{\mathrm{RHE}}\right)$, intermediate potentials $(0.3<E<0.7$ $\mathrm{V}_{\mathrm{RHE}}$ ), and high potentials $\left(E>0.7 \mathrm{~V}_{\mathrm{RHE}}\right)$.

\section{Low Potentials $(E<0.3$ V RHE $)$}

We first note differences in the initial relative intensity of the $\mathrm{CO}_{\mathrm{L}}$ band for the $\mathrm{Pt} / \mathrm{C}$ and $\mathrm{Pt} / \mathrm{C} / \mathrm{WO}_{3}$ catalysts, measured at $0.04 \mathrm{~V}_{\mathrm{RHE}}$. In the case of $\mathrm{Pt} / \mathrm{C}$, the $\mathrm{CO}_{\mathrm{L}}: \mathrm{CO}_{\mathrm{B}}$ band intensity ratio is approximately $4: 1$ at this potential, whereas for $\mathrm{Pt} / \mathrm{C} / \mathrm{WO}_{3}$ this ratio is notably higher, at approximately 9:1. Interpretation of these ratios in terms of site occupancy between linear and bridge bonded CO is not straightforward, however, we believe the higher $\mathrm{CO}_{\mathrm{L}}: \mathrm{CO}_{\mathrm{B}}$ intensity ratio in this case results directly from a higher proportion of linearly bonded $\mathrm{CO}$ in the $\mathrm{Pt} / \mathrm{C} / \mathrm{WO}_{3}$ catalyst, characteristic of a higher overall saturation $\mathrm{CO}$ coverage (i.e. more dense $\mathrm{CO}$ packing). A complicating factor here is the phenomenon of intensity transfer ${ }^{39,40,42}$ between $\mathrm{CO}_{\mathrm{B}}$ and $\mathrm{CO}_{\mathrm{L}}$ bands, but this would suggest more pronounced $\mathrm{CO}$ molecular interactions in the presence of $\mathrm{WO}_{3}$, which would also be consistent with a higher saturation coverage of $\mathrm{CO}$. As noted above, it is possible that the $\mathrm{WO}_{3}$ induces the formation of compact $\mathrm{CO}$ islands which might facilitate intensity transfer but again this would not be in keeping with the direction of the $\mathrm{CO}_{\mathrm{L}}$ wavenumber shift observed.

Analysis of the $\mathrm{CO}$ behaviour for Pt/C (Figure 7a) across the low-potential region between $0.04 \mathrm{~V}_{\mathrm{RHE}}$ and $0.3 \mathrm{~V}_{\mathrm{RHE}}$ shows a drop in relative CO coverage of approximately $10 \%$; further examination shows this drop can be attributed almost entirely to a change in the $\mathrm{CO}_{\mathrm{L}}$ signal, with very little change to the $\mathrm{CO}_{\mathrm{B}}$ signal. At first sight this appears to be inconsistent with our $\mathrm{H}_{2}-\mathrm{CO}$ stripping measurements which show no $\mathrm{H}_{2}$-oxidation current within this potential region. A possible explanation can be extrapolated from the work of López-Cudero et al. in their examination of the pre-peak in $\mathrm{N}_{2}$ - $\mathrm{CO}$ stripping measurements with $\mathrm{Pt} / \mathrm{C}$ catalysts ${ }^{43}$. They note that a maximum $\mathrm{CO}$ coverage of $\theta=0.68$ can be achieved in a $\mathrm{CO}$-free solution if the adsoprtion potential is more negative than $0.3 \mathrm{~V}_{\text {RHE. }}$. If the adsorption potential is increased to $0.5 \mathrm{~V}_{\text {RHE }}$, the saturation coverage decreases to $\theta=0.63$, showing that the saturation coverage is a function of potential. It follows that adsorbing at a low potential $(0.04$ $\mathrm{V}_{\mathrm{RHE}}$ ), then subsequently stepping the potential positively with the electrode allowed to equilibrate at each step would have a similar effect, in that each potential step would result in the maximum saturation coverage at that potential being realised. López-Cudero et al. note that the maximum surface coverage required to completely block $\mathrm{H}_{2}$ adsoprtion (and subsequent oxidation) is $\theta=0.63$; so, if our starting coverage (CO Total $=1$ ) is $\theta=0.68$, a valid assumption, a decrease to $\theta=0.63$ would equate to a drop in CO Total of $\sim 0.08$, without the onset of $\mathrm{H}_{2-}$ oxidation, which accounts for the observed results from both $\mathrm{H}_{2}-\mathrm{CO}$ stripping and in situ ATR-IR measurements. 

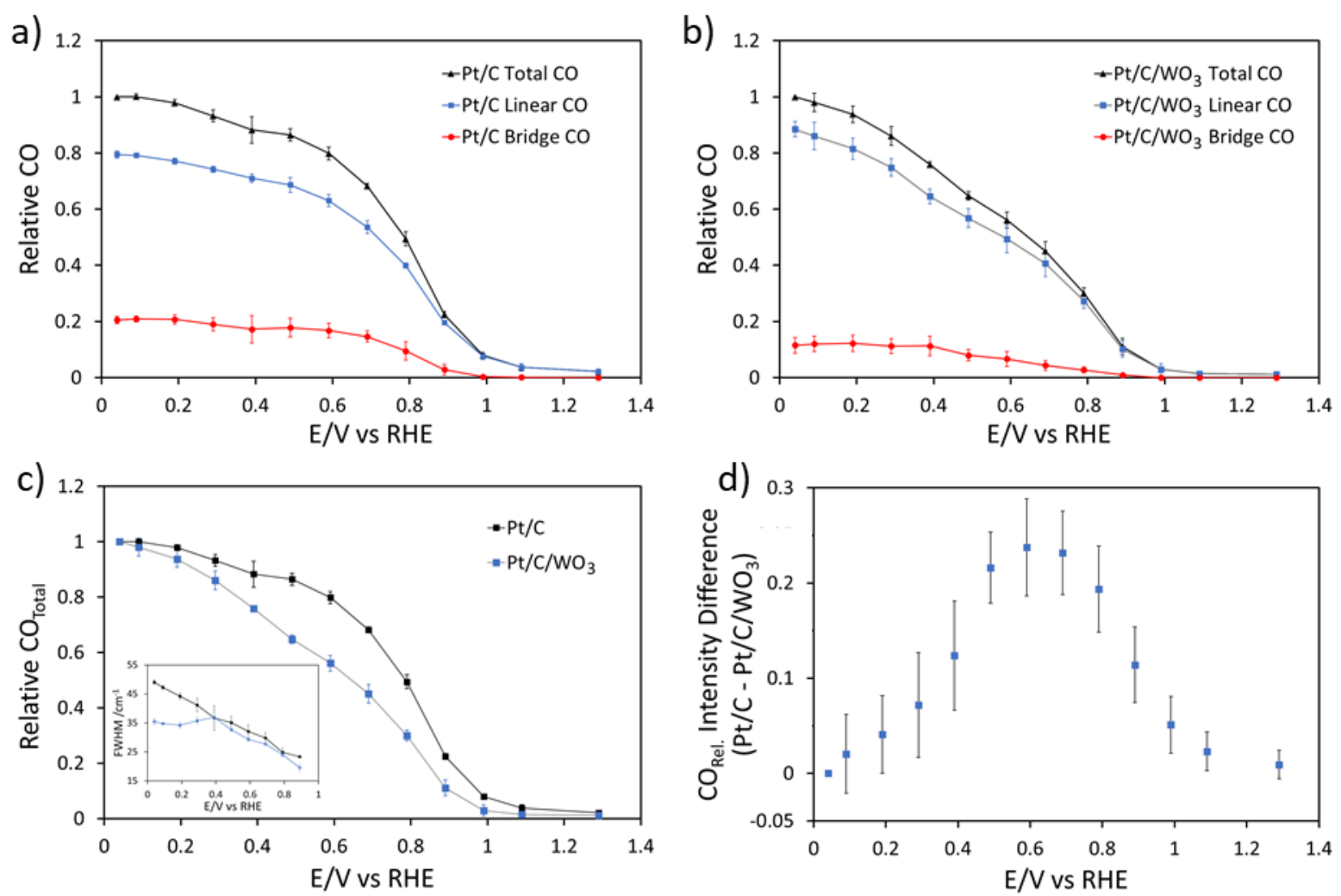

Figure 7 | ATR-IR Electrochemical Data Plots. a) Relative CO signal intensity for Pt/C catalyst. b) Relative CO signal intensity for $\mathrm{Pt} / \mathrm{C} / \mathrm{WO}_{3}$ catalyst. c) Comparative plot of total $\mathrm{CO}$ signal intensity for $\mathrm{Pt} / \mathrm{C}$ and $\mathrm{Pt} / \mathrm{C} / \mathrm{WO}_{3}$ catalysts (inset; linear $\mathrm{CO}$ FWHM comparison of $\mathrm{Pt} / \mathrm{C}$ and $\mathrm{Pt} / \mathrm{C} / \mathrm{WO}_{3}$ catalysts). d) $\mathrm{CO}$ signal intensity difference plot. Error bars reflect the standard deviation determined from triplicate measurement.

We observe a small difference between $\mathrm{Pt} / \mathrm{C}$ and $\mathrm{Pt} / \mathrm{C} / \mathrm{WO}_{3}$ in this region, with a slight drop in relative $\mathrm{CO}$ coverage in the presence of $\mathrm{WO}_{3}$ (compared to $\mathrm{Pt} / \mathrm{C}$ ) at potentials up to $0.3 \mathrm{~V} \mathrm{RHE}$. This difference can be seen more clearly in the comparison of total $\mathrm{CO}$ signal shown in Figure 7c. This difference is consistent with the chronoamperometry data in Figure 4, which showed a slow electrochemical oxidation of $\mathrm{H}_{2}$ at $0.1 \mathrm{~V}_{\mathrm{RHE}}$, indicating that some $\mathrm{CO}$ oxidation is possible, albeit at very slow rates, in the presence of $\mathrm{WO}_{3}$ even at this low potential.

\section{Intermediate Potentials $\left(0.3 \mathrm{~V}_{\mathrm{RHE}}<E<0.7 \mathrm{~V}_{\mathrm{RHE}}\right)$}

In this intermediate potential region we observe a significant difference in relative $\mathrm{CO}$ coverage between $\mathrm{Pt} / \mathrm{C}$ and $\mathrm{Pt} / \mathrm{C} / \mathrm{WO}_{3}$ with increasing potential. Figure $7 \mathrm{~d}$, in which the difference in relative total $\mathrm{CO}$ signal between the two catalysts is plotted as a function of potential, shows that this reaches a maximum at $\sim 0.6 \mathrm{~V}_{\mathrm{RHE}}$, after which the two catalysts behave similarly at $E>0.9 \mathrm{~V}_{\mathrm{RHE}}$. The onset of this significant difference ( 0.3 $\left.\mathrm{V}_{\mathrm{RHE}}\right)$ aligns with the potential at which the $\mathrm{WO}_{3}$ component is fully oxidised, as determined by in situ Raman spectroscopy (Figure $5)$.

It is at the beginning of this potential window $\left(\sim 0.3 \mathrm{~V}_{\mathrm{RHE}}\right)$ that we also observe broadening of the $\mathrm{CO}_{\mathrm{L}}$ band for the $\mathrm{Pt} / \mathrm{C} / \mathrm{WO}_{3}$ catalyst as shown in the inset of Figure $7 \mathrm{c}$ in which the full width at half maximum (FWHM) for the $\mathrm{CO}_{\mathrm{L}}$ band is plotted as a function of potential. Between 0.2 and $0.4 \mathrm{~V}_{\mathrm{RHE}}$ the $\mathrm{CO}_{\mathrm{L}}$ peak for $\mathrm{Pt} / \mathrm{C} / \mathrm{WO}_{3}$ broadens significantly before narrowing at higher potentials, whereas for $\mathrm{Pt} / \mathrm{C}$ we observe a gradual narrowing with increasing potential across the entire potential range. The latter is consistent with an initially high diversity of $\mathrm{CO}$ bonding states which decreases as $\mathrm{CO}$ molecules begin to be removed from the surface as the potential is stepped more positive. The contrasting behaviour observed in the presence of $\mathrm{WO}_{3}$ may result from two possible effects: (i) an increase in the range of Pt-CO bonding environments associated with the oxidation of $\mathrm{W}^{\mathrm{V}}$ to $\mathrm{W}^{\mathrm{VI}}$, followed by their removal upon $\mathrm{CO}$ oxidation; (ii) dipole-dipole coupling between adjacent adsorbed $\mathrm{CO}$ molecules causes a narrowing of the $\mathrm{CO}_{\mathrm{L}}$ bandwidth at high $\mathrm{CO}$ coverages (low potentials) compared to the $\mathrm{Pt} / \mathrm{C}$ catalyst. As the potential is increased this dipole-dipole coupling is alleviated due to the decreased coverage, 
leading to line broadening. Based on the lower $\mathrm{CO}_{\mathrm{L}}$ wavenumber observed in the presence of $\mathrm{WO}_{3}$ we postulate that (i) is the more likely to be the dominant effect.

\section{High Potentials $\left(\mathrm{E}>0.7 \mathrm{~V}_{\text {RHE}}\right)$}

The relative $\mathrm{CO}$ signal intensities begin to converge for $\mathrm{Pt} / \mathrm{C}$ and $\mathrm{Pt} / \mathrm{C} / \mathrm{WO}_{3}$ above $0.6 \mathrm{~V}_{\mathrm{RHE}}$, indicating that the $\mathrm{CO}$ oxidation characteristics are similar in this region, and that $\mathrm{WO}_{3}$ does not significantly affect the oxidation characteristics in this potential range (i.e. the "conventional" CO oxidation mechanism operates for both samples). 


\section{Discussion}

Based on the above observations, we conclude that the $\mathrm{WO}_{3}$-assisted $\mathrm{CO}$ tolerance is imparted through a bifunctional mechanism, with the $\mathrm{WO}_{3}$ itself mediating oxidation of Pt-adsorbed $\mathrm{CO}$ at potentials lower than on $\mathrm{Pt}$ in the absence of $\mathrm{WO}_{3}$, as well as providing surface oxygen species, as has previously been proposed ${ }^{14}$. Whilst $\mathrm{WO}_{3}$ clearly induces electronic effects, as indicated by the increased Pt-CO $\pi$-back-bonding observed by ATR-IR spectroscopy, these are most pronounced at low potentials where the $\mathrm{WO}_{3}$ is partially reduced and little $\mathrm{CO}$ oxidation is observed, so they are not likely to contribute beneficially to the $\mathrm{CO}$ tolerance mechanism.

Evidence for the direct role of the tungsten centres in $\mathrm{CO}$ oxidation is based on the potential observed for sustained $\mathrm{H}_{2}$ oxidation from a CO-contaminated surface $\left(E \geq 0.3 \mathrm{~V}_{\mathrm{RHE}}\right)$ being coincident with the transition from tungsten bronze $\left(\mathrm{H}_{x} \mathrm{WO}_{3}\right)$ to $\mathrm{WO}_{3}$, as identified by in situ Raman spectroscopy, suggesting that the rapid regeneration of $\mathrm{W}^{\mathrm{VI}}$ is necessary for this catalytic mechanism. We also observe slow $\mathrm{CO}$ oxidation activity in the $E<0.3 \mathrm{~V}_{\mathrm{RHE}}$ region, as indicated by the small $\mathrm{CO}$ depletion in the ATR-IR signal for the $\mathrm{Pt} / \mathrm{C} / \mathrm{WO}_{3}$ catalyst (Figure 7) and electrochemical oxidation current (Figure 3 and Figure 4), indicative of a stoichiometric reaction where the $\mathrm{H}_{\mathrm{x}} \mathrm{WO}_{3}$ (characterised by in situ Raman spectroscopy) oxidises $\mathrm{CO}$ to give $\mathrm{CO}_{2}$, resulting in further reduction of the tungsten bronze.

Taken together, we propose the mechanism depicted in Figure 8, where $\mathrm{W}^{\mathrm{VI}}$ is identified as the active redox species that oxidises $\mathrm{CO}_{\text {ads,Pt }}$ in the presence of water in a stoichiometric chemical step (reaction a) to form $\mathrm{CO}_{2}$ and a tungsten bronze. Rapid electrochemical oxidation of the tungsten bronze (reaction $\mathbf{b}$ ) only becomes possible at potentials above $\sim 0.3 \mathrm{~V}_{\mathrm{RHE}}$, which allows completion of the catalytic cycle. It is worth noting that, whilst the electrochemical oxidation of $\mathrm{W}^{\mathrm{V}}$ may be thermodynamically feasible at potentials above $\sim 0.2 \mathrm{~V}_{\mathrm{RHE}}$ (based on the position of the redox peaks in Figure $3 \mathrm{~b}$ ), the slow electron transfer kinetics between $0.2 \mathrm{~V}_{\text {RHE }}$ and $0.3 \mathrm{~V}_{\text {RHE }}$ will mean reaction $\mathbf{b}$ becomes rate determining in this potential range.

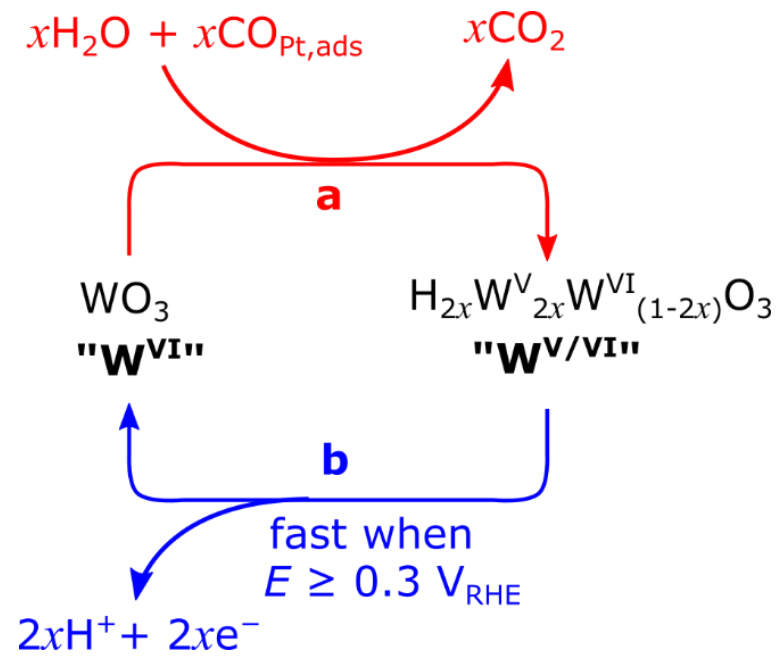

Figure 8 | Proposed catalytic cycle for $\mathrm{CO}$ oxidation by $\mathrm{WO}_{3}$, featuring a chemical (a, red) and electrochemical (b, blue) steps.

The results and mechanism discussed above do not identify the precise surface species involved in the CO oxidation mechanism but are consistent with literature proposals invoking surface $\mathrm{W}-\mathrm{OH}$ groups. These are formed on $\mathrm{WO}_{3}$ surfaces by water adsorption under ambient conditions ${ }^{44-47}$ and especially in the presence of hydrogen and Pt surfaces ${ }^{3,4}$ with the corresponding reduction of $\mathrm{W}^{\mathrm{VI}}$ to $\mathrm{W}^{\mathrm{V}}$. These 'activated' $\mathrm{OH}_{\text {ads }}$ groups then provide the oxygen atom for $\mathrm{CO}$ oxidation, with the resultant electrons transferred to the tungsten oxide. Micoud et al. ${ }^{15}$ also identified these sites as important in promoting a bifunctional mechanism for CO oxidation but we extend this to suggest the role of $\mathrm{W}^{\mathrm{VI}}$ species as the key oxidant. Although the in situ Raman spectroscopy technique used to characterise these phases is not specific to the surface, we suggest that due to fast proton diffusion though $\mathrm{WO}_{3}$ and tungsten bronze phases in the presence of water ${ }^{34,48}$, and high electronic conductivity of the tungsten bronzes ${ }^{49}$, the surface oxidation states will rapidly equilibrate with the bulk within the nanosized particles. Moreover, the measured bulk oxidation state of the tungsten oxide rationalises the ability of the material to accept electrons (with proton compensation) from $\mathrm{CO}$ oxidation at a given potential, and mediate them through the $\mathrm{W}^{\mathrm{VI} / \mathrm{V}}$ redox couple to the external circuit to be measured by electrochemical techniques. These results are 
therefore complementary to literature reports on the surface properties by providing a mechanism for sustained electrocatalytic oxidation through the bulk. Additionally, possibly corroborating this mechanism is the observation that under increasingly positive potentials the Raman stretching frequency for the $\mathrm{W}-\mathrm{O}$ bond is lowered (Figure $5 \mathrm{~b}$ ), indicating weakening of the bond. As such we propose that as the electrode potential increases, the progressive restoration of $\mathrm{W}^{\mathrm{VI}}$ concentration is coupled with simultaneous bond weakening, and thus activation of $\mathrm{OH}$ groups, providing the local environment for $\mathrm{CO}$ oxidation.

In addition to the redox effects discussed above, $\mathrm{CO}$ binding on $\mathrm{Pt}$ is influenced by the presence of $\mathrm{WO}_{3}$ (ATR-IR), presumably due to range dependent electronic effects (i.e. SMSI) originating from $\mathrm{W}^{\mathrm{VI}}$, which is increasing throughout the active redox potential range of $\mathrm{WO}_{3}$ (Figure 5). It remains quantitatively unclear at this stage how the energetics (active potential range) of charge transfer processes are affected by variations in catalyst/co-catalyst dispersion/distribution across the entire potential range.

Taking the catalytic cycle shown in Figure 8 as the predominant mechanism, the rate of $\mathrm{CO}$ oxidation on $\mathrm{Pt} / \mathrm{C} / \mathrm{WO}_{3}$ catalysts within typical operational fuel cells ( $\mathrm{E}_{\text {anode }}<0.2 \mathrm{~V}_{\mathrm{RHE}}$ ) will be limited by the electrochemically slow replenishment of $\mathrm{W}^{\mathrm{VI}}$ and the resulting inability to fully complete the catalytic cycle at this potential. In this case $\mathrm{WO}_{3}$ may offer some limited $\mathrm{CO}$ tolerance enhancements but further measurements using an operating fuel cell would be required to establish the $\mathrm{CO}$ concentration at which the rate of $\mathrm{CO}$ oxidation becomes greater than the rate of accumulation. The present study has shown shown that $\mathrm{WO}_{3}$ is most effective in improving the $\mathrm{CO}$ tolerance of Pt/C catalysts in the potential region $0.3 \geq E \geq 0.4 \mathrm{~V}_{\mathrm{RHE}}$ making these catalyst systems suitable for applications where an anodic overpotential of this magnitude is likely, such as in direct methanol fuel cells. 


\section{Conclusions}

We have shown that the inclusion of a $\mathrm{WO}_{3}$ powder co-catalyst in a $\mathrm{Pt} / \mathrm{C}$ electrode provides a measurable increase in the $\mathrm{CO}$ tolerance, specifically resulting from the low-potential oxidation of adsorbed $\mathrm{CO}$ via a bifunctional mechanism. We have determined that the rate of $\mathrm{CO}$ oxidation below $0.3 \mathrm{~V}_{\mathrm{RHE}}$ is relatively low, and there is a step-change in the rate above $0.3 \mathrm{~V}_{\mathrm{RHE}}$, coinciding with oxidation to $\mathrm{WO}_{3}$ within the electrode, leading us to conclude that fully oxidized $\mathrm{W}^{\mathrm{VI}}$ is essential for this reaction. We have proposed a possible mechanism wherein the chemistry of $\mathrm{WO}_{3}$ provides both $\mathrm{W}^{\mathrm{VI}}$ species and the surface oxygen species for the low-potential oxidation of $\mathrm{CO}$ on the platinum surface. We note that this relies on sufficient contact area between the Pt and $\mathrm{WO}_{3}$, but the data presented suggests this can be achieved by physically mixing $\mathrm{Pt} / \mathrm{C}$ with $\mathrm{WO}_{3}$.

The use of in situ ATR-IR and Raman spectroelectrochemistry has allowed us to identify the role of the $\mathrm{W}^{\mathrm{VI}}$ species for the first time, and the potential-dependence of $\mathrm{W}^{\mathrm{VI}}$ within the electrode, which can be used to identify the limitations of $\mathrm{WO}_{3}$-containing electrocatalysts, and the applications for which these catalysts are best suited. More generally, the observation that a physical mixture of commercially available $\mathrm{Pt} / \mathrm{C}$ and pre-synthesised $\mathrm{WO}_{3}$ can improve $\mathrm{CO}$ tolerance to a similar extent to previously reported $\mathrm{WO}_{3}$-supported $\mathrm{Pt}$ has the potential to provide substantial cost benefits in the context of future catalyst materials development and optimisation.

\section{Supporting Information}

Figure $\mathrm{S} 1$; $\mathrm{Cu}$-ECSA voltammograms of $\mathrm{Pt} / \mathrm{C}, \mathrm{WO}_{3} / \mathrm{C}$, and $\mathrm{GC}$ electrodes, Figure $\mathrm{S} 2$; $\mathrm{XRD}$ analysis of tungsten oxide, Figure S3; comparison of hydrogen oxidation current of various catalysts and GC electrode, Figure S4; cyclic voltammetry of catalyst materials and GC electrode in supporting electrolyte.

\section{Acknowledgements}

XPS data collection was performed at the EPSRC National Facility for XPS ('HarwellXPS'), operated by Cardiff University and UCL, under contract No. PR16195. Research was supported by Enocell Ltd. and the Analysis for Innovators Programme, funded by Innovate UK and the UK Department of Business, Energy and Industrial Strategy (BEIS). 


\section{References}

(1) Sun, Y. China to support hydrogen and fuel cell vehicles to go green https://www.reuters.com/article/us-china-autos-hydrogen/china-to-support-hydrogen-and-fuel-cellvehicles-to-go-green-idUSKCN1RZ17X (accessed Jul 31, 2019).

(2) Guerrero Moreno, N.; Cisneros Molina, M.; Gervasio, D.; Pérez Robles, J. F. Approaches to Polymer Electrolyte Membrane Fuel Cells (PEMFCs) and Their Cost. Renew. Sustain. Energy Rev. 2015, 52, 897906. https://doi.org/10.1016/j.rser.2015.07.157.

(3) NewsWire. Ballard to Offer World's First PEM Fuel Cell Product Using Non Precious Metal Catalyst https://www.newswire.ca/news-releases/ballard-to-offer-worlds-first-pem-fuel-cell-product-usingnon-precious-metal-catalyst-644077753.html (accessed Feb 27, 2019).

(4) Hydrogen and Fuel Cells: Technologies and Market Perspectives; Töpler, J., Lehmann, J., Eds.; 2016. https://doi.org/10.1007/978-3-662-44972-1.

(5) Schmidt, V. M.; Brockerhoff, P.; Hohlein, B.; Menzer, R.; Stimming, U. Utilization of Methanol for Polymer Electrolyte Fuel Cells in Mobile Systems. J. Power Sources 1994, 49, 299-313.

(6) Baschuk, J. J.; Li, X. Carbon Monoxide Poisoning of Proton Exchange Membrane Fuel Cells. Int. J. Energy Res. 2001, 25 (8), 695-713. https://doi.org/10.1002/er.713.

(7) Igarashi, H.; Fujino, T.; Zhu, Y.; Uchida, H.; Watanabe, M. CO Tolerance of Pt Alloy Electrocatalysts for Polymer Electrolyte Fuel Cells and the Detoxification Mechanism. Phys. Chem. Chem. Phys. 2001, 3 (3), 306-314. https://doi.org/10.1039/b007768m.

(8) Ticanelli, E.; Beery, J. G.; Paffett, M. T.; Gottesfeld, S. An Electrochemical, Ellipsometric, and Surface Science Investigation of the PtRu Bulk Alloy Surface. J. Electroanal. Chem. 1989, 258, 61-77. https://doi.org/10.1016/0022-0728(89)85162-9.

(9) Gasteiger, H. A.; Markovié, N. M.; Ross, P. N. H2 and CO Electrooxidation on Well-Characterized Pt, Ru, and Pt-Ru. 1. Rotating Disk Electrode Studies of the Pure Gases Including Temperature Effects. J. Phys. Chem 1995, 99, 8290-8301.

(10) Kabbabi, A.; Faure, R.; Durand, R.; Beden, B.; Hahn, F.; Leger, J. M.; Lamy, C. In Situ FTIRS Study of the Electrocatalytic Oxidation of Carbon Monoxide and Methanol at Platinum-Ruthenium Bulk Alloy Electrodes. J. Electroanal. Chem. 1998, 444 (1), 41-53. https://doi.org/10.1016/S0022-0728(97)005585 .

(11) Yajima, T.; Wakabayashi, N.; Uchida, H.; Watanabe, M. Adsorbed Water for the Electro-Oxidation of Methanol at Pt-Ru Alloy. Chem. Commun. 2003, 3 (7), 828-829. https://doi.org/10.1039/b212197b.

(12) Krausa, M.; Vielstich, W. Study of the Electrocatalytic Influence of Pt/Ru and Ru on the Oxidation of Residues of Small Organic Molecules. J. Electroanal. Chem. 1994, 379 (1-2), 307-314. https://doi.org/10.1016/0022-0728(94)87152-3.

(13) Lin, W. F.; Iwasita, T.; Vielstich, W. Catalysis of CO Electrooxidation at Pt, Ru, and PtRu Alloy. An in Situ FTIR Study. J. Phys. Chem. 1999, 103, 3250-3257. https://doi.org/10.1186/1029-242X-2013-144.

(14) Micoud, F.; Maillard, F.; Bonnefont, A.; Job, N.; Chatenet, M. The Role of the Support in CO Ads Monolayer Electrooxidation on Ptnanoparticles: Pt/WOx vs.Pt/C. Phys. Chem. Chem. Phys. 2010, 12, 1182-1193. https://doi.org/10.1039/B915244J.

(15) Chen, K. Y. Anodic Oxidation of Impure H2 on Teflon-Bonded Pt-Ru/WO3/C Electrodes. J. Electrochem. Soc. 1995, 142 (10), 185-187. https://doi.org/10.1149/1.2050038.

(16) Hou, Z.; Yi, B.; Yu, H.; Lin, Z.; Zhang, H. CO Tolerance Electrocatalyst of PtRu-HxMeO3/C (Me = W, Mo) Made by Composite Support Method. J. Power Sources 2003, 123, 116-125. https://doi.org/10.1016/S0378-7753(03)00515-9.

(17) L.W. Niedrach, I. B. W. Performance of Carbon Monoxide in Low-Temperature Fuel Cells Containing 
Oxide Catalysts. Electrochem. Technol. 1965, No. 3, 270-275.

(18) Liu, J.; Jiang, L. Electrostatic Self-Assembly of Pt Nanoparticles on Hexagonal Tungsten Oxide as an Active CO-Tolerant Hydrogen Oxidation Electrocatalyst. Int. J. Hydrogen Energy 2018, 43 (18), 89448952. https://doi.org/10.1016/J.IJHYDENE.2018.03.131.

(19) Olu, P. Y.; Ohnishi, T.; Ayato, Y.; Mochizuki, D.; Sugimoto, W. Insights into the Enhanced Tolerance to Carbon Monoxide on Model Tungsten Trioxide-Decorated Polycrystalline Platinum Electrode. Electrochem. commun. 2016, 71, 69-72. https://doi.org/10.1016/j.elecom.2016.08.008.

(20) Micoud, F.; Maillard, F.; Gourgaud, A.; Chatenet, M. Unique CO-Tolerance of Pt-WOxmaterials. Electrochem. commun. 2009, 11 (3), 651-654. https://doi.org/10.1016/j.elecom.2009.01.007.

(21) Brković, S. M.; Nikolić, V. M.; Marčeta Kaninski, M. P.; Pašti, I. A. Pt/C Catalyst Impregnated with Tungsten-Oxide - Hydrogen Oxidation Reaction vs. CO Tolerance. Int. J. Hydrogen Energy 2019, 44 (26), 13364-13372. https://doi.org/10.1016/j.ijhydene.2019.03.270.

(22) Jusys, Z.; Kaiser, J.; Behm, R. J. Electrooxidation of CO and H2/CO Mixtures on a Carbon-Supported Pt Catalyst - A Kinetic and Mechanistic Study by Differential Electrochemical Mass Spectrometry. Phys. Chem. Chem. Phys. 2001, 3 (21), 4650-4660. https://doi.org/10.1039/b104617a.

(23) Woodward, F. E.; Hanafey, M. K.; N, R. C. (1984) 43-63. J. Electroanal. Chem. 1984, 167, $43-63$.

(24) Schmidt, T. J.; Noeske, M.; Gasteiger, H. A.; Behm, R. J.; Britz, P.; Brijoux, W.; Bönnemann, H. Letters Electrocatalytic Activity of PtRu Alloy Colloids for $\mathrm{CO}$ and CO/H 2 Electrooxidation: Stripping Voltammetry and Rotating Disk Measurements. ACS Surfaces Colloids 1997, 13 (10), 2591-2595.

(25) Green, C. L.; Kucernak, A. Determination of the Platinum and Ruthenium Surface Areas in PlatinumRuthenium Alloy Electrocatalysts by Underpotential Deposition of Copper. I. Unsupported Catalysts. J. Phys. Chem. B 2002, 106 (5), 1036-1047. https://doi.org/10.1021/jp0131931.

(26) Varga, K.; Zelenay, P.; Wieckowski, A. Adsorption of Anions on Ultra-Thin Metal Deposits on SingleCrystal Electrodes. II: Voltammetric and Radiochemical Study of Bisulfate Adsorption on Pt(111) and Pt(Poly) Electrodes Containing Copper Adatoms. J. Electroanal. Chem. 1992, 330 (1-2), 453-467. https://doi.org/10.1016/0022-0728(92)80324-W.

(27) Reichman, B. The Electrochromic Process at WO[Sub 3] Electrodes Prepared by Vacuum Evaporation and Anodic Oxidation of W. J. Electrochem. Soc. 1979, 126 (4), 583. https://doi.org/10.1149/1.2129091.

(28) Lillard, R. S. The Nature of Oxide Films on Tungsten in Acidic and Alkaline Solutions. J. Electrochem. Soc. 1998, 145 (8), 2718. https://doi.org/10.1149/1.1838704.

(29) Hitchman, M. L. Analysis of Equilibrium Potentials of Hydrogen Tungsten Bronzes. J. Electroanal. Chem. 1977, 85 (1), 135-144. https://doi.org/10.1016/S0022-0728(77)80159-9.

(30) Pyper, O.; Kaschner, A.; Thomsen, C. In Situ Raman Spectroscopy of the Electrochemical Reduction of WO3 Thin Films in Various Electrolytes. Sol. Energy Mater. Sol. Cells 2002, 71, 511-522. https://doi.org/10.1016/S0927-0248(01)00103-9.

(31) Cazzanelli, E.; Vinegoni, C.; Mariotto, G.; Kuzmin, A.; Purans, J. Raman Study of the Phase Transitions Sequence in Pure WO3 at High Temperature and in HxWO3 with Variable Hydrogen Content. Solid State lonics 1999, 123 (1), 67-74. https://doi.org/10.1016/S0167-2738(99)00101-0.

(32) Hardwick, L. J.; Holzapfel, M.; Novák, P.; Dupont, L.; Baudrin, E. Electrochemical Lithium Insertion into Anatase-Type TiO2: An in Situ Raman Microscopy Investigation. Electrochim. Acta 2007, 52 (17), 53575367. https://doi.org/10.1016/j.electacta.2007.02.050.

(33) Benson, J. E.; Kohn, H. W.; Boudart, M. On the Reduction of Tungsten Trioxide Accelerated by Platinum and Water. J. Catal. 1966, 5 (2), 307-313. https://doi.org/10.1016/S0021-9517(66)80013-1.

(34) Xi, Y.; Zhang, Q.; Cheng, H. Mechanism of Hydrogen Spillover on WO3(001) and Formation of HxWO3 (x $=0.125,0.25,0.375$, and 0.5). J. Phys. Chem. C 2014, $118(1), 494-501$. 
https://doi.org/10.1021/jp410244c.

(35) Kunimatsu, K.; Sato, T.; Uchida, H.; Watanabe, M. Adsorption/Oxidation of CO on Highly Dispersed Pt Catalyst Studied by Combined Electrochemical and ATR-FTIRAS Methods: Oxidation of CO Adsorbed on Carbon-Supported Pt Catalyst and Unsupported Pt Black. Langmuir 2008, 24 (7), 3590-3601. https://doi.org/10.1021/la702441x.

(36) Arenz, M.; Mayrhofer, K. J. J.; Stamenkovic, V.; Blizanac, B. B.; Tomoyuki, T.; Ross, P. N.; Markovic, N. M. The Effect of the Particle Size on the Kinetics of CO Electrooxidation on High Surface Area Pt Catalysts. J. Am. Chem. Soc. 2005, 127 (18), 6819-6829. https://doi.org/10.1021/ja043602h.

(37) Stamenkovic, V.; Chou, K. C.; Somorjai, G. A.; Ross, P. N.; Markovic, N. M. Vibrational Properties of CO at the Pt(111)-Solution Interface: The Anomalous Stark-Tuning Slope. J. Phys. Chem. B 2005, 109 (2), 678-680. https://doi.org/10.1021/jp044802i.

(38) Liu, R.; Iddir, H.; Fan, Q.; Hou, G.; Bo, A.; Ley, K. L.; Smotkin, E. S. Potential-Dependent Infrared Absorption Spectroscopy of Adsorbed CO and X-Ray Photoelectron Spectroscopy of Arc-Melted SinglePhase Pt, PtRu, PtOs, PtRuOs, and Ru Electrodes. J. Phys. Chem. B 2000, 104 (15), 3518-3531. https://doi.org/10.1021/jp992943s.

(39) Chang, S. C.; Weaver, M. J. Coverage-Dependent Dipole Coupling for Carbon Monoxide Adsorbed at Ordered Platinum(111)-Aqueous Interfaces: Structural and Electrochemical Implications. J. Chem. Phys. 1990, 92 (7), 4582-4594. https://doi.org/10.1063/1.457719.

(40) Severson, M. W.; Stuhlmann, C.; Villegas, I.; Weaver, M. J. Dipole-Dipole Coupling Effects upon Infrared Spectroscopy of Compressed Electrochemical Adlayers: Application to the Pt(111)/CO System. J. Chem. Phys. 1995, 103 (22), 9832-9843. https://doi.org/10.1063/1.469950.

(41) Wasileski, S. A.; Weaver, M. J.; Koper, M. T. M. Potential-Dependent Chemisorption of Carbon Monoxide on Platinum Electrodes: New Insight from Quantum-Chemical Calculations Combined with Vibrational Spectroscopy. J. Electroanal. Chem. 2001, 500 (1-2), 344-355. https://doi.org/10.1016/S0022-0728(00)00420-4.

(42) Persson, B. N. J.; Ryberg, R. Vibrational Interaction between Molecules Adsorbed on a Metal Surface: The Dipole-Dipole Interaction. Phys. Rev. B 1981, 24 (12), 6954-6970.

https://doi.org/10.1103/PhysRevB.24.6954.

(43) López-Cudero, A.; Solla-Gullón, J.; Herrero, E.; Aldaz, A. CO Electrooxidation on Carbon Supported Platinum Nanoparticles: Effect of Aggregation. J. Electroanal. Chem. 2010, 644 (2), 117-126. https://doi.org/10.1016/J.JELECHEM.2009.06.016.

(44) Kanan, S. M.; Lu, Z.; Cox, J. K.; Bernhardt, G.; Tripp, C. P. Identification of Surface Sites on Monoclinic WO3 Powders by Infrared Spectroscopy. Langmuir 2002, 18 (5), 1707-1712. https://doi.org/10.1021/la011428u.

(45) Kulesza, P. J.; Faulkner, L. R. Electrocatalysis at a Novel Electrode Coating of Nonstoichiometric Tungsten(VI,V) Oxide Aggregates. J. Am. Chem. Soc. 1988, 110 (15), 4905-4913. https://doi.org/10.1021/ja00223a006.

(46) Yoshiike, N.; Kondo, S. Electrochemical Properties of WO3 x(H2O): I. The Influences of Water Adsorption and Hydroxylation. J. Electrochem. Soc. 1993, 130, 2283-2287.

(47) Albanese, E.; Di Valentin, C.; Pacchioni, G. H2O Adsorption on WO3 and WO3-x (001) Surfaces. ACS Appl. Mater. Interfaces 2017, 9 (27), 23212-23221. https://doi.org/10.1021/acsami.7b06139.

(48) Vannice, M. A.; Boudart, M.; Fripiat, J. J. Mobility of Hydrogen in Hydrogen Tungsten Bronze. J. Catal. 1970, 17 (3), 359-365. https://doi.org/10.1016/0021-9517(70)90112-0.

(49) Whittingham, M. S. Hydrogen Motion in Oxides: From Insulators to Bronzes. Solid State lonics 2004, 168 (3-4), 255-263. https://doi.org/10.1016/j.ssi.2003.08.056. 


\section{TOC Graphic}
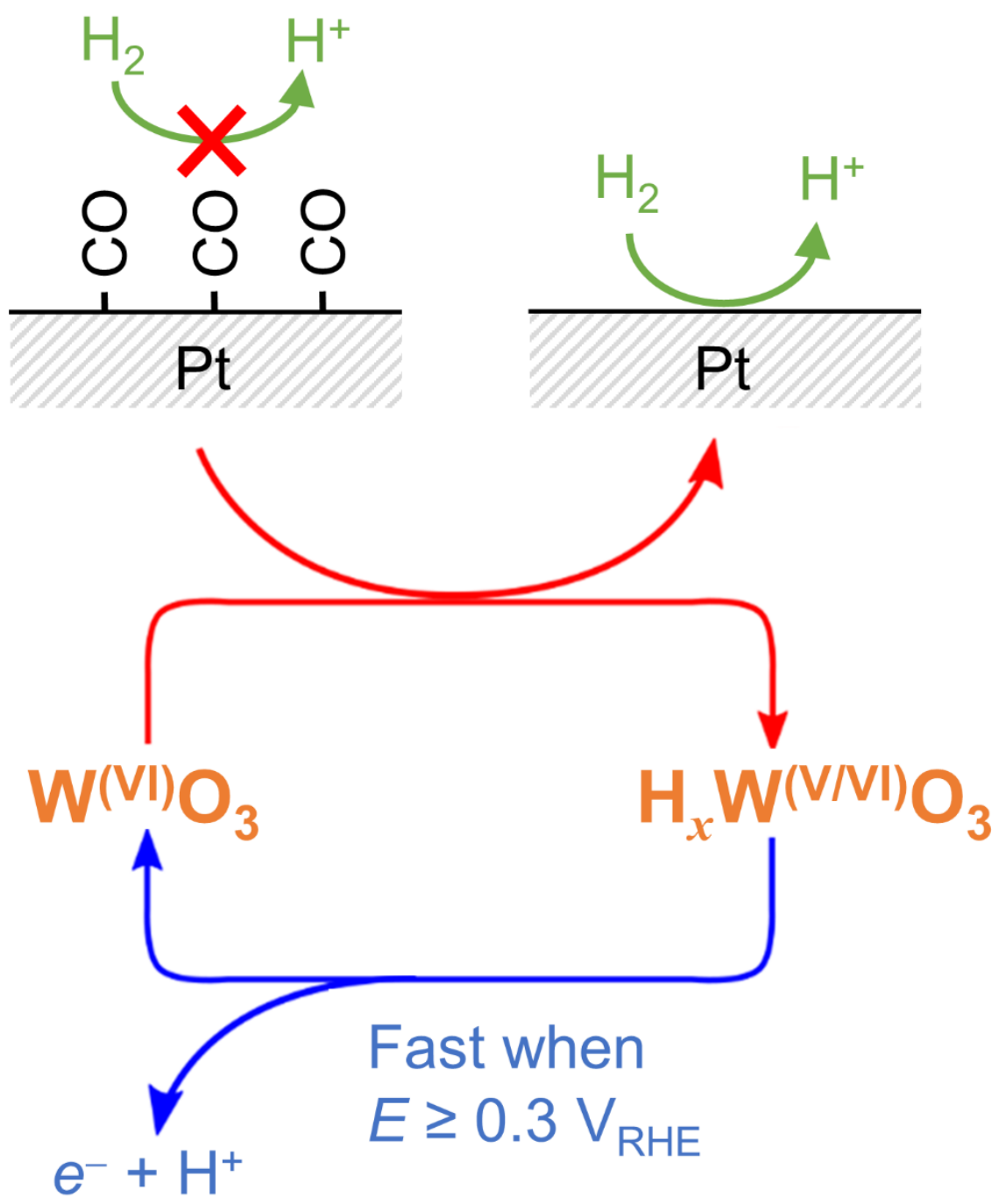